\title{
Cardiac cAMP: production, hydrolysis, modulation and detection
}

\author{
Cédric Boularan * and Céline Gales * \\ Institut des Maladies Métaboliques et Cardiovasculaires, Institut National de la Santé et de la Recherche Médicale, U1048, \\ Université Toulouse III Paul Sabatier, Toulouse, France
}

Cyclic adenosine $3^{\prime}, 5^{\prime}$-monophosphate (cAMP) modulates a broad range of biological processes including the regulation of cardiac myocyte contractile function where it constitutes the main second messenger for $\beta$-adrenergic receptors' signaling to fulfill positive chronotropic, inotropic and lusitropic effects. A growing number of studies pinpoint the role of spatial organization of the CAMP signaling as an essential mechanism

OPEN ACCESS

Edited by:

Apostolos Zarros,

University of Glasgow, UK

Reviewed by:

Jinsong Bian,

National University of Singapore,

Singapore

Joshua B. Rubin,

Washington University School of

Medicine, USA

*Correspondence:

Cédric Boularan and Céline Gales, Institut des Maladies Métaboliques et

Cardiovasculaires - I2MC, Institut

National de la Santé et de la Recherche Médicale UMR1048, 1 , Avenue Jean-Poulhès - BP84225,

31432 Toulouse, France cedric.boularan@inserm.fr;

celine.gales@inserm.fr

Specialty section:

This article was submitted to

Experimental Pharmacology and Drug

Discovery,

a section of the journal

Frontiers in Pharmacology

Received: 31 July 2015

Accepted: 03 September 2015

Published: 01 October 2015

Citation:

Boularan C and Gales C (2015)

Cardiac CAMP: production, hydrolysis,

modulation and detection.

Front. Pharmacol. 6:203.

doi: 10.3389/fphar.2015.00203 to regulate CAMP outcomes in cardiac physiology. Here, we will briefly discuss the complexity of cAMP synthesis and degradation in the cardiac context, describe the way to detect it and review the main pharmacological arsenal to modulate its availability.

Keywords: GPCR, resonance energy transfer, phosphodiesterase, protein kinase A (PKA), Cyclic AMP

\section{Introduction}

In cardiomyocytes, the influx of $\mathrm{Ca}^{2+}$ ions through voltage-dependent $\mathrm{L}$-type $\mathrm{Ca}^{2+}$ channels (LTCC) plays an essential role in cardiac excitability and in coupling excitation to contraction of these cells. The depolarizing current through LTCC (ICa) contributes to the plateau phase of the cardiac action potential as well as to pacemaker activity in nodal cells (Shaw and Colecraft, 2013). This influx of $\mathrm{Ca}^{2+}$ triggers the release of intracellular stores of $\mathrm{Ca}^{2+}$ from the sarcoplasmic reticulum via the Ryanodine receptor (RyR), which results in activation of myofilaments contraction. Alterations in density or function of LTCC have been implicated in a variety of cardiovascular diseases, including atrial fibrillation (Van Wagoner et al., 1999) or heart failure (Mukherjee and Spinale, 1998). Cyclic adenosine $3^{\prime}, 5^{\prime}$-monophosphate (cAMP) is the main second messenger of the $\beta$-adrenergic receptor signaling inducing phosphorylation of the LTCC and the ryanodine receptor to increase the amount of intracellular $\mathrm{Ca}^{2+}$ necessary for heart contractility (responsible for positive chronotropic and inotropic effects during sympathetic stimulation) (Guellich et al., 2014). Moreover, catecholamine stimulated $\beta$-adrenergic receptor not only leads to cAMP effector dependent-troponin I phosphorylation to allow faster force development and shortening during systole and faster force relaxation and re-lengthening during diastole but also mediated cAMP effector dependent-phospholamban phosphorylation responsible for $\mathrm{Ca}^{2+}$ re-uptake in the sarcoplasmic reticulum and myofilament relaxation (lusitropic effects) (Bers, 2008). However sustained stimulation of this pathway may be detrimental thus leading to cardiac remodeling and development of heart failure (Brodde, 1993; Kiuchi et al., 1993). Thus, the proper physiological cardiac function relies on tight control of cellular cAMP concentration by fine-tuning the balance between cAMP synthesis and degradation. In mammalian cells, cAMP is produced by adenylyl cyclases (AC). Extracellular stimuli such as neurotransmitters, hormones, chemokines, lipid mediators, and drugs, can modulate $\mathrm{AC}$ activity to increase or decrease cAMP production by binding to a large number of transmembrane $G$ protein-coupled receptors (GPCRs). The degradation of cAMP to AMP is catalyzed by phosphodiesterases (PDE) that are regulated by intracellular nucleotide concentrations, phosphorylation, binding 
of $\mathrm{Ca}^{2+} /$ calmodulin and other regulatory proteins while cAMP efflux out of the cell is mediated by cyclic nucleotide efflux transporters. Over the years, several genetic models have been created to assess the role of the cAMP synthesis and hydrolysis proteins in cardiac physiology (Table 1). Once cAMP is produced it activates a set of diverse proteins, including

TABLE 1 | Cardiac phenotype for cAMP synthesis, hydrolysis and transporter proteins adapted from Guellich et al. (2014).

\begin{tabular}{|c|c|c|c|c|c|c|}
\hline Class & $\begin{array}{l}\text { Protein } \\
\text { family }\end{array}$ & $\begin{array}{l}\text { Substrate } \\
\text { affinity }\end{array}$ & Protein & Cardiac function & Available model & References \\
\hline \multirow[t]{6}{*}{ AC } & & & AC1 & Modulates If pacemaker current & & Mattick et al., 2007 \\
\hline & & & AC5 & Regulates contractility $\beta$-adrenergic dependent & AC5 Knockout & $\begin{array}{l}\text { Iwamoto et al., 2003; Okumura } \\
\text { et al., 2003a,b; Tang et al., } 2006\end{array}$ \\
\hline & & & & $\begin{array}{l}\text { Myocardardial contractility increases LV } \\
\text { function increases heart rate, reduces inotropic, } \\
\text { lusitropic and chronotropic response to } \beta 1 \text { AR }\end{array}$ & AC5 Transgenic & $\begin{array}{l}\text { Tepe et al., 1999; Esposito et al., } \\
\text { 2008; Lai et al., } 2013\end{array}$ \\
\hline & & & AC6 & $\begin{array}{l}\text { LV systolic and diastolic dysfunction } \\
\text { LV contractility increases with } \beta \text { AR stimulation } \\
\text { enhanced contractile function }\end{array}$ & $\begin{array}{l}\text { AC6 Knockout } \\
\text { AC6 Transgenic }\end{array}$ & $\begin{array}{l}\text { Gao et al., 1999, 2008; Phan } \\
\text { et al., 2007; Tang et al., } 2008 \text {, } \\
\text { 2010; Guellich et al., } 2010\end{array}$ \\
\hline & & & AC8 & Enhances basal intrinsic contractility & $\begin{array}{l}\text { Cardiomyocyte specific AC8 } \\
\text { Transgenic }\end{array}$ & Lipskaia et al., 2000 \\
\hline & & & sAC & $\begin{array}{l}\text { Apoptosis of coronary endothelial cells heart } \\
\text { rate increase }\end{array}$ & ADCY10 knockout & $\begin{array}{l}\text { Kumar et al., 2009; M.G. } \\
\text { Informatics }^{1}\end{array}$ \\
\hline \multirow[t]{11}{*}{ PDE } & PDE1 & $1-100 \mu \mathrm{M}$ & PDE1A & $\begin{array}{l}\text { Cardiomyocyte hypertrophy } \\
\text { Cardiac fibroblast activation and cardiac fibrosis }\end{array}$ & & Miller et al., 2011 \\
\hline & & & PDE1B & & PDE1B Knockout & $\begin{array}{l}\text { Yu et al., 1997; M.G. } \\
\text { Informatics }^{2}\end{array}$ \\
\hline & & & PDE1C & & PDE1C knockout mice & $\begin{array}{l}\text { Vandeput et al., 2007; M.G. } \\
\text { Informatics }^{3}\end{array}$ \\
\hline & PDE2 & $30 \mu \mathrm{M}$ & PDE2A & $\begin{array}{l}\text { PDE2 expression is increased in experimental } \\
\text { heart failure }\end{array}$ & & \\
\hline & & & & L-type Ca2+ channel activity Contractility & PDE2A: embryonic death (EI7) & $\begin{array}{l}\text { Hartzell and Fischmeister, 1986; } \\
\text { Fischmeister et al., } 2005\end{array}$ \\
\hline & PDE3 & $0.08 \mu \mathrm{M}$ & PDE3A & $\begin{array}{l}\text { Regulates } \beta \text {-adrenergic signaling, cardiac } \\
\text { contractility, pacemaking, and output reduces } \\
\text { cardiomyocyte apoptosis and prevents } \\
\text { ischemia/reperfusion induced myocardial } \\
\text { infarction cardiac contractility, LTCC activity }\end{array}$ & $\begin{array}{l}\text { PDE3A knockout mice } \\
\text { Cardiomyocyte PDE3A } \\
\text { overexpressing mice }\end{array}$ & $\begin{array}{l}\text { Tarpey et al., 2003; Ding et al., } \\
\text { 2005a,b; Sun et al., 2007; } \\
\text { Molenaar et al., 2013; Iwaya } \\
\text { et al., } 2014\end{array}$ \\
\hline & PDE4 & $1-4 \mu \mathrm{M}$ & PDE4A & $?$ & PDE4A knockout mice & Jin et al., 2005 \\
\hline & & & PDE4B & Arrhythmogenesis & PDE4B knockout mice & Leroy et al., 2011 \\
\hline & & & PDE4D & $\begin{array}{l}\beta \text {-adrenergic signaling } \\
\text { RyR2 hyperphosphorylation, arrhythmia }\end{array}$ & PDE4D knockout mice & $\begin{array}{l}\text { Lehnart et al., 2005; Bruss et al., } \\
2008\end{array}$ \\
\hline & PDE7 & $0.03-0.2 \mu \mathrm{M}$ & PDE7A & $?$ & PD17A Knockout & Yang et al., 2003 \\
\hline & PDE8 & $0.04-0.8 \mu \mathrm{M}$ & PDE8A & $\begin{array}{l}\text { Regulation of } \mathrm{LTCC} \mathrm{Ca}^{2+} \text { signaling, Ryr2 } \mathrm{Ca}^{2+} \\
\text { load }\end{array}$ & PDE8A knockout mice & Patrucco et al., 2010 \\
\hline \multicolumn{3}{|c|}{ Cyclic nucleotide efflux transporter } & $\begin{array}{l}\text { ABCC4 } \\
\text { ABCC5 }\end{array}$ & $\begin{array}{l}\text { Enhances contractility and cardiac hypertrophy } \\
?\end{array}$ & MRP4 Knockout mice & Sassi et al., 2012 \\
\hline
\end{tabular}

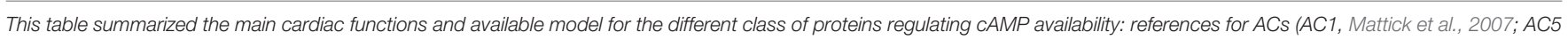
KO, Iwamoto et al., 2003; Okumura et al., 2003a,b; Tang et al., 2006; AC5 Tg, Tepe et al., 1999; Esposito et al., 2008; Lai et al., 2013; AC6 KO, Tang et al., 2008, 2010; AC6 Tg,

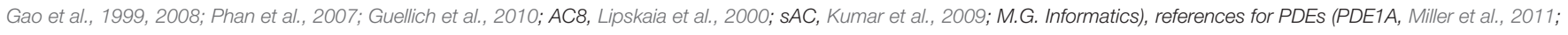

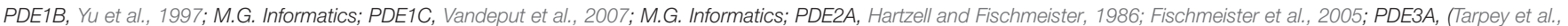

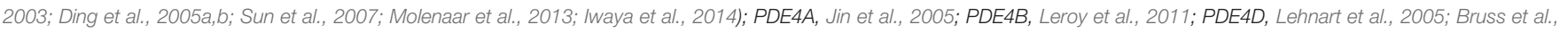
2008; PDE7, Yang et al., 2003; PDE8, Patrucco et al., 2010) and references for cyclic nucleotide transporter (ABCC4, Sassi et al., 2012).

${ }^{1}$ http://www.informatics.jax.org/marker/MGI:2660854. Informatix JAX.

${ }^{2}$ http://www.informatics.jax.org/marker/MGI:97523. JAX.

${ }^{3} \mathrm{http}: / /$ www.informatics.jax.org/reference/marker/MGI:108413. JAX. 
cAMPdependent-protein kinase (PKA) or cAMP-dependent exchange proteins (Epac), the two main cAMP effectors to mediate downstream signaling as well as cyclic nucleotidegated ion channels (CNGC) and POPDC proteins (Beavo and Brunton, 2002). From the compartmentation hypothesis proposed by Brunton et al., in which cAMP microdomains are distinctly coupled to cellular functions (Brunton et al., 1981), a variety of technologies has been developed to study in vivo the different localizations and organization around macromolecular complexes to ensure a fine-tuned spatiotemporal compartmentation of cAMP production (for detailed reviews (Baillie, 2009; Edwards et al., 2012; Perera and Nikolaev, 2013). Recently, these tools led to the identification of a $\beta 2$ adrenergic-dependent CAMP compartmentation defect in failing cardiomyocytes (Nikolaev et al., 2010). In this review, we will focus on CAMP in synthesis and hydrolysis in cardiology, the way to detect it and how to manipulate this CAMP pathway.

\section{cAMP in the Cardiac Tissue}

\section{cAMP Synthesis}

Adenylyl cyclases (AC) are ubiquitous enzymes that catalyze the conversion of Adenosine triphosphate (ATP) into cAMP and pyrophosphate. ACs structure consists in 12 transmembrane domains divided into 2 hydrophobics domains (6 transmembrane domains each) and 2 main intracellular loops called $\mathrm{C} 1$ and $\mathrm{C} 2$ that naturally dimerize to form the catalytic domain (Figure 1A). In mammals, 9 transmembrane and 1 soluble AC (sAC) encoded by different genes have been identified and have different regulatory mechanisms (Willoughby and Cooper, 2007). Mammalian ACs are strongly activated by $\mathrm{Mn}^{2+}$ or $\mathrm{Mg}^{2+}$ (Tesmer et al., 1999) and inhibited by millimolar concentrations of free $\mathrm{Ca}^{2+}$ probably acting as a $\mathrm{Mg}^{2+}$ competitor (Mou et al., 2009) but at submicromolar concentrations, $\mathrm{Ca}^{2+}$ can activate $\mathrm{AC}$ via calmodulin $(\mathrm{CaM})$ throught its binding to a putative helical structure on the $\mathrm{C} 1 \mathrm{~b}$ region (Halls and Cooper, 2011). More precisely AC1, 3, and 8 are $\mathrm{Ca}^{2+} / \mathrm{CaM}$ sensitive isoforms which localize in lipid rafts while $\mathrm{AC} 2,4,7$, and 9 are $\mathrm{Ca}^{2+} / \mathrm{CaM}$ insensitive and are excluded from these membrane domains (Willoughby and Cooper, 2007). On the contrary, biochemical studies on membrane preparations revealed that AC5 and AC6 could be inhibited by $\mathrm{Ca}^{2+}$ (independently of $\mathrm{CaM}$ ) in the submicromolar range (Guillou et al., 1999; Hu et al., 2002). Along with nitric oxide (NO), Hydrogen sulfide (H2S) is a biological gaseous transmitter able to modulate cAMP production. Using NO donors, the gasotransmitter NO is thought to attenuate forskolin-stimulated AC5 and AC6 isoforms activities without altering their basal activity on membrane from rat striatum (Hudson et al., 2001). Even if $\mathrm{H} 2 \mathrm{~S}$ is a poisonous gas used as a chemical reagent, $\mathrm{H} 2 \mathrm{~S}$ is endogenously formed in mammalian cells from cysteine by the action of cystathionine $\beta$-synthase with serine as a by-product at a concentration around $50-160 \mu \mathrm{mol} / \mathrm{L}$ (Goodwin et al., 1989). In the central nervous system, H2S enhances NMDA receptor-mediated response via cAMP production (Kimura, 2000) while in cardiac context it can also suppressed AC activity and, therefore, decreased forskolin-stimulated cAMP accumulation in different cell lines and tissue (Lim et al., 2008; Yong et al., 2008). In the cardiomyocytes, expression of AC1, $\mathrm{AC} 5, \mathrm{AC} 6, \mathrm{AC} 8$, and sAC has been detected and most function as modulators of inotropic and chronotropic $\beta$-adrenergic receptor $(\beta$-AR) signaling output (Table 1) but AC5 and AC6 represent the dominant isoform (Defer et al., 2000). Along with AC distribution within membrane microdomains (Efendiev and Dessauer, 2011), cAMP synthesis is spatially restricted by localization of activating receptors like $\beta 1$-adrenergic receptors or $\beta 2$-adrenergic receptors at caveolae or non-caveolae plasma membrane domains (Rybin et al., 2000; Ostrom et al., 2001).
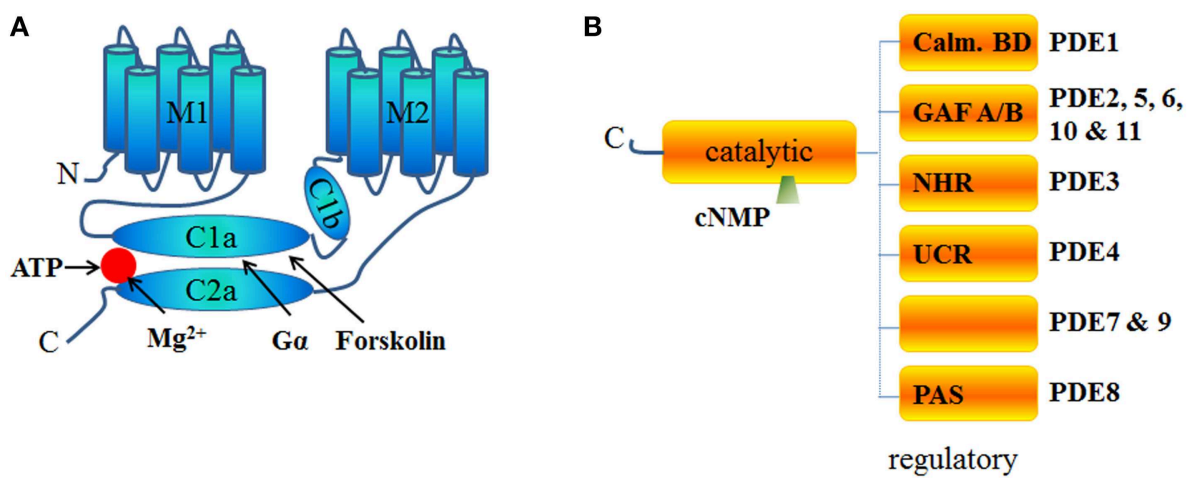

FIGURE 1 | Schematic structure of ACs and PDEs. (A) Structure of Adenylyl cyclase is comprised of 2 transmembrane domains (M1 and M2 6 helixes each) and 2 cytosolic domains ( $\mathrm{C} 1$ and $\mathrm{C} 2$ ) subdivided into a and b domains. $\mathrm{C} 1$ and $\mathrm{C} 2$ contain the catalytic core, the $\mathrm{G} \alpha$ and the forskolin binding sites and other regulatory sites. C2b domain is almost inexistent in all AC isoforms. (B) PDEs are homodimers with the exception of PDE1 and PDE6 (usually heterotetramers). PDEs have an $\mathrm{NH}_{2}$-terminal regulatory domain and share a conserved catalytic domain located in the $\mathrm{COOH}$-terminal portion of the protein. The structure of the regulatory domain varies according the PDE isoform. GAF is an acronym for cGMP-specific PDE, Adenylyl cyclases and FhIA, NHR for N-terminal Hydrophobic Region, PAS for Per-ARNT-Sim and Calm. BD for calmodulin binding domain. No known domains are present in PDE7 or PDE9 regulatory C-terminal part. PDE4 proteins are classified as "long" or "short" isoforms, depending on the presence or absence of two highly conserved domains, Upstream Conserved Region 1 (UCR 1) and Upstream Conserved Region 2 (UCR 2) which interact to form a regulatory module that may influence catalytic activity by a PKA-dependent phosphorylation mechanism (Houslay, 2001; Mackenzie et al., 2002). 
Moreover, specific A-kinase anchor proteins (AKAP) complexes (Kapiloff et al., 2014) have been identified as a potential molecular mechanism for the formation of specific cAMP microdomains (Kapiloff et al., 2014). The AKAPs constitute signaling hub proteins that scaffold on a same membrane domain the AC and the regulatory subunit of protein kinase A (PKA) cAMP effector, thus confining the enzyme activity to discrete locations within the cell. Cardiac myocytes exhibit at least four distinct AKAP complexes: AKAP79/150 (aka AKAP5) with AC5/6 (Nichols et al., 2010); mAKAP $\beta$ (aka AKAP6) with AC2/5 (Kapiloff et al., 2009), YOTIAO (aka AKAP9) with AC2/9 (Piggott et al., 2008), and AKAP18 $\delta$ with PKA (Fraser et al., 1998) (Figure 2).

\section{cAMP Elimination: Phosphodiesterases and Cyclic Nucleotide Efflux Transporters \\ Phosphodiesterases}

Cyclic AMP is hydrolyzed exclusively by cyclic nucleotide PDEs classified in 11 families and encoded by at least 21 different genes with the existence of some splice variants (Omori and Kotera, 2007). PDEs are structured around a catalytic domain containing the cyclic nucleotide binding site conserved across all families and a regulatory $\mathrm{N}$-terminus varying according to the different PDEs (Figure 1B). In the heart, 8 PDE families have been described: PDE1; PDE2, PDE3, PDE4, PDE5, PDE7, PDE8, and PDE9. Among them, PDE1, PDE2, and PDE3 are dual-specificity enzymes that can hydrolyze both cAMP and
cGMP while PDE4, PDE7, PDE8 selectively hydrolyze cAMP and conversely PDE5, PDE9 selectively hydrolyze cGMP. Of the cAMP-hydrolyzing PDEs expressed in the heart, cGMP inhibits PDE3 and possibly PDE1, whereas PDE2 is activated by cGMP (detailed review in Zaccolo and Movsesian, 2007). Jurevicius and Fischmeister (1996a,b) provided the first direct evidence for PDE-mediated cAMP signaling compartmentation, showing that PDE inhibition allowed local $\beta$-adrenergic stimulation to enhance $\mathrm{Ca}^{2+}$ currents in frog ventricular myocytes (Jurevicius and Fischmeister, 1996a,b). Later on, imaging approaches confirmed that PDEs play a key role in shaping the intracellular cAMP gradient in rat neonatal cardiomyocytes (Zaccolo et al., 2000; Zaccolo and Pozzan, 2002). Like ACs, PDEs have also been shown to be compartmented by AKAPs complexes. Thus, specific cAMP hydrolysis-based PDE4 enzyme were shown to interact with mAKAP for PDE4D3 (Dodge et al., 2001); AKAP9 for PDE4D3 (Taskén et al., 2001), AKAP95 (aka AKAP8) for PDE4A (Asirvatham et al., 2004), AKAP149 for PDE4A (Asirvatham et al., 2004) (Figure 2).

\section{Cyclic Nucleotide Efflux Transporters}

In addition to PDEs and ACs, the intracellular concentration of cAMP is regulated by its efflux into the extracellular space through a specific transmembrane transport system named multidrug resistance proteins (MRP) (Cheepala et al., 2013) that belongs to the ATP-binding cassette (ABC) transporter

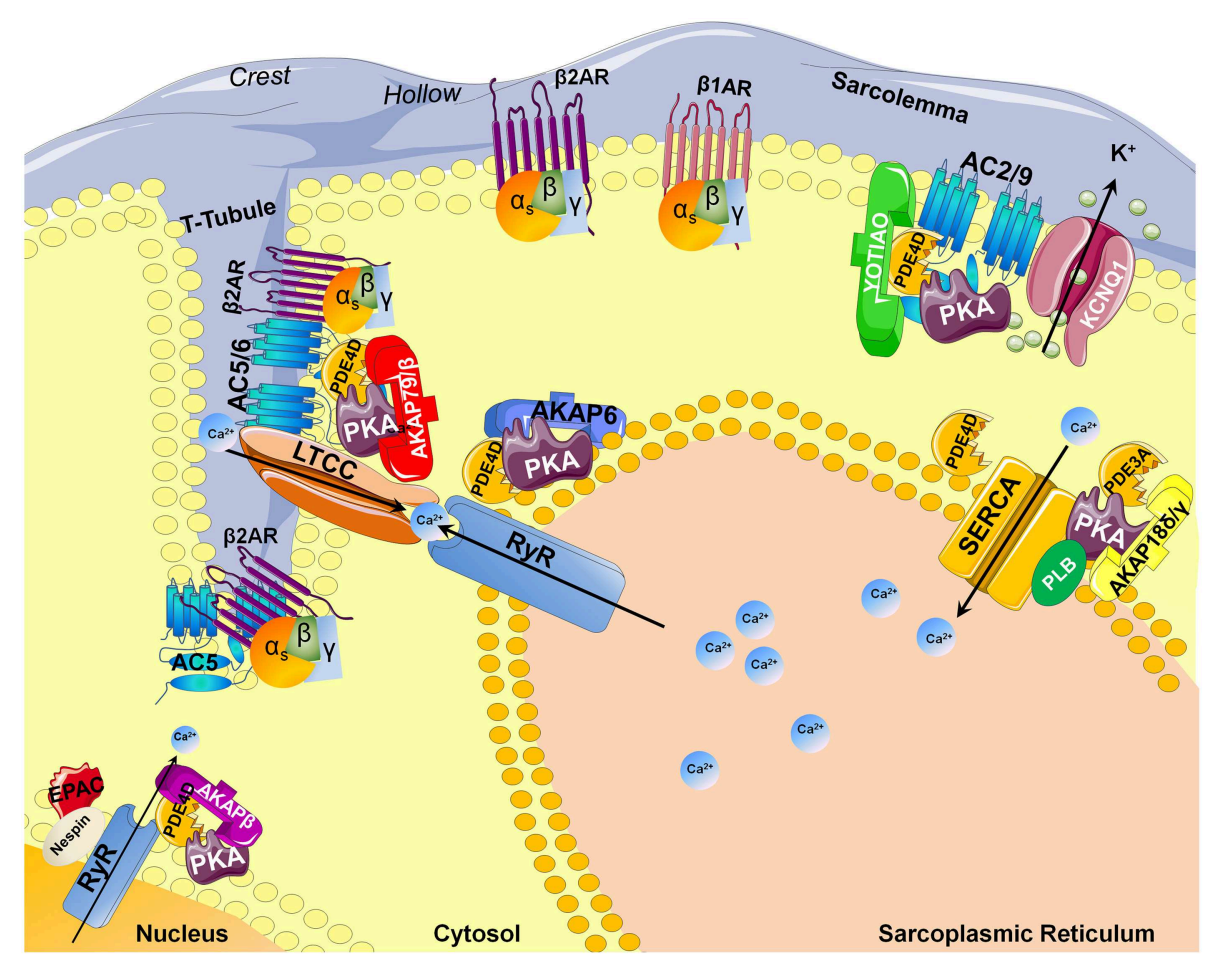

FIGURE 2 | AKAP-dependent AC and PDE compartmentalizations in the cardiomyocyte. Abbreviations stand for: AKAP, A-kinase anchor proteins; PKA, Protein Kinase A; $\beta 2 A R / \beta 1 A R$, beta adrenergic receptor; PLN, Phospholamban; EPAC, cAMP-dependent exchange proteins; AC, Adenylyl cyclase; RyR, Ryanodine Receptor; SERCA, sarco/endoplasmic reticulum $\mathrm{Ca}^{2+}$-ATPase; KCNQ1, potassium channel voltage gated KQT-like subfamily Q; PDE, Phosphodiesterase; T-tubule, Transverse tubule; LTCC, L-type calcium channel. 
superfamily (subfamily C). Three of them (MRP4 aka ABCC4, MRP5 aka ABCC5, and MRP8 aka ABCC11) have the ability to actively extrude cAMP and cGMP from the cell (Kruh and Belinsky, 2003) and in cardiac myocytes, MRP4 has been shown to enhance cAMP formation, contractility, and cardiac hypertrophy (Sassi et al., 2012). The compartimentation of MRPs expression may also play an important role in the intra- and extracellular cAMP signaling processes. For instance, caveolin-rich membrane MRP4 localization (Sassi et al., 2008) could explain the local MRP4-modulated contraction of cardiac myocytes induced by activation of $\beta$-adrenoceptor (Sellers et al., 2012).

\section{cAMP in Heart Failure}

Heart failure (HF) occurs when the heart is unable to pump sufficiently to maintain blood flow to meet the body's needs. Around $2 \%$ of adults have HF and this percentage increases to 6$10 \%$ for people over the age of 65 (McMurray and Pfeffer, 2005). The HF syndrome arises as a consequence of an abnormality in cardiac structure, function, rhythm, or conduction. As stated in introduction, cAMP primarily, but not exclusively, controls beating frequency, force of contraction and relaxation, essentially through the $\beta$-adrenergic signaling pathway. This pathway is necessary for the beneficial effects of catecholamines on cardiac contractility. During heart failure set up, increased sympathetic activity drives the $\beta \mathrm{AR}$ overstimulation in cardiomyocytes, thus promoting higher intracellular cAMP signals for compensatory cardiac function in the heart (Baker, 2014). However, chronic $\beta A R$ stimulation and uncontrolled cellular cAMP signals have been shown to affect heart function in a much more detrimental way responses such as cell apoptosis (Zhu et al., 2003) and the loss of pump function (Michel et al., 1990; Engelhardt et al., 1999; Lohse et al., 2003), ultimately leading to HF setup. During the ongoing of the disease, a down-regulation of $\beta 1 \mathrm{AR}$ expression (Nikolaev et al., 2010) is correlated with a modulation of Gai proteins (Eschenhagen et al., 1992a,b) expression to attenuate cAMP synthesis. The ratio between $\beta 1 A R$ and $\beta 2 A R$ converts the latter to be the major $\beta A R$ subtype in failing hearts. Interestingly, associated with this receptor expression imbalance, the $\beta 2 \mathrm{AR}$ dominant-induced cAMP signal is broadly distributed in the failing heart (Nikolaev et al., 2010) compare to a compartmentalized cAMP signal in physiological condition. The functional output of this broadly distributed cAMP signal in modulating contractile properties in failing hearts has to be studied. In failing cardiomyocytes, chronic $\beta 2 \mathrm{AR}$ stimulation also promotes CaMKII-dependent contractile responses which has a pronounced role in promoting the development of cardiac hypertrophy, myocyte apoptosis, cardiac dysfunction and arrhythmias by causing sarcoplasmic reticulum $\mathrm{Ca}^{2+}$ overload (Anderson et al., 2011). Inhibition of CaMKII is able to ameliorate cardiac remodeling and reduce cardiac arrhythmias after myocardial infarction (Zhang et al., 2005). Although the direct link between cAMP and CaMKII is still missing, the detrimental CaMKII activity in cardiomyocytes could be related to dysregulation of distribution of cAMP signals under chronic $\beta \mathrm{AR}$ stimulation. $\mathrm{HF}$ is a complex process where the various components in the cAMP signaling pathway constitute potential pharmacological targets.

\section{Modulation of cAMP Concentration in the Cardiac Tissue}

\section{Modulation of cAMP Production Targeting Adenylyl Cyclases \\ Pharmacological AC activators}

The most prominent AC activator is forskolin (FSK). FSK, a diterpene extracted from the plant Coleus forskohlii, directly activates all AC isoforms except AC9. Despite a strong hydrophobic property, its action is not limited to the native membrane-bound form of the enzyme since it can readily stimulate some synthetic soluble ACs. FSK binds to the same cleft that contains the active site of AC (Tesmer et al., 1997) where it glues together its two cytoplasmic domains (Figure 1A) by a combination of hydrophobic and hydrogen-binding interactions (Zhang et al., 1997). Based on equilibrium dialysis experiments of the $\mathrm{C} 1$ and $\mathrm{C} 2$ domains of type $\mathrm{AC} 5$ and $\mathrm{AC} 2$, respectively, the C1/C2 complex binds only one Gs $\alpha$, one ATP, and one FSK molecule (Dessauer et al., 1997). However, FSK has been shown to also inhibit a number of membrane transport proteins and channel proteins like Glucose transporter or voltage dependent $\mathrm{K}^{+}$channel (Laurenza et al., 1989). As Protein kinase C (PKC) activates AC2 by phosphorylating it on Thr-1057 (Böl et al., 1997), another alternative, but more restrictive one to activate $\mathrm{AC}$, relies on the use of Phorbol 12-myristate 13-acetate (PMA) a phorbol diester and a potent tumor promoter known to activate PKC signaling. Thus, PKC-dependent phosphorylation of AC-C1 domain induces AC activation (Ebina et al., 1997). However, one must be cautious on the use of PMA as a specific AC-activator since PMA has also been reported to have actions on non-kinase proteins including chimaerins, RasGRP, and Unc-13/Munc-13 (Han and Meier, 2009; Kazanietz et al., 1995).

\section{Pharmacological AC inhibitors}

As schemed in Figure 1A, ACs are structured around 2 hydrophobic domains and 2 main intracellular loops containing the catalytical domain and the diterpene regulatory site. Based on this structure, ACs inhibitors can be divided into 4 groups (reviewed in Seifert et al., 2012): (i) the inhibitors competing with the ATP at the catalytic site like MANT-GTP (Gille and Seifert, 2003), (ii) the uncompetitive P-site inhibitors like $2^{\prime}, 5^{\prime}$-dideoxyadenosine- $3^{\prime}$-tetraphosphate Vidarabine [aka 9- $\beta$ D-arabinofuranosyladenine (ara-A)] (Seifert, 2014) or NKY80 (a cell-permeable quinazolinone) to name a few, which work by stabilizing a pyrophosphate-bound transition state (Dessauer et al., 1999; Onda et al., 2001), (iii) the allosteric non-competitive inhibitors targeting the diterpene regulatory site like BODIPYFS in presence of divalent cations (Erdorf et al., 2011), and (iv) the allosteric non-competitive inhibitors targeting alternated and unknown site like calmidazolium (Haunsø et al., 2003). Even though some specificity has been assigned to some of the molecules listed, to our knowledge, those inhibitors have not been accurately examined at all ACs isoforms, thus preventing 
any formal conclusion only based on their use to assess the involvement of AC activity.

\section{Targeting G-protein Coupled Receptor Signaling}

We previously mentioned that cAMP constitutes the master second messenger of $\beta$-adrenergic receptor signaling which belong to the G protein-coupled receptors (GPCRs) family. According to conventional knowledge, 7 transmembrane GPCRs at the plasma membrane convert extracellular signals into intracellular ones through canonical heterotrimeric $G$ proteins which transduce signals from GPCRs to secondary effectors thus leading to the second messengers production and the propagation of the signal through ensuing regulation of numerous downstream intracellular signaling targets (Gilman, 1987). G proteins localized on the cytoplasmic side of the plasma membrane and are composed of a guanine nucleotide binding $\alpha$ subunit $(G \alpha)$ and a $\beta \gamma$ dimer $(G \beta \gamma)$, both constitutively associated in the G protein inactive state. Upon GPCR activation, the $G \alpha \beta \gamma$ protein associates with the receptor thus allowing GDP/GTP exchange on the G $\alpha$ GTPase domain, leading to subsequent $\mathrm{G} \alpha-\mathrm{GTP}$ and $\mathrm{G} \beta \gamma$ dissociation both regulating downstream specific signaling targets (Denis et al., 2012). Intrinsic GTPase activity of the G $\alpha$ then allows GTP hydrolysis and to turn off the $G$ protein activity to its initial inactive $\mathrm{G} \alpha \beta \gamma$ associated state. $\mathrm{G}$ proteins have been classified into five subfamilies (Gi/o, Gs, Gq/11, and G12/13) according to the secondary effector of the $\mathrm{G} \alpha$ subunit (Denis et al., 2012). Thus, isoforms of the Gai/o family classically inhibit ACs and cAMP production while, conversely, isoforms from the Gas family activate ACs to favor cAMP production. It follows that modulation of the activity of cardiac expressed Gai- or Gascoupled receptors either through the use of selective GPCR agonists and antagonists or $\mathrm{G}$ proteins activators or inhibitors will directly alter the G protein activity and cAMP availability.

\section{GPCR agonists and antagonists}

In the human genome, it is estimated that the GPCR superfamily consists in $\sim 600-1000$ receptors (Lander et al., 2001; Vassilatis et al., 2003; Fredriksson and Schioth, 2005) where $\approx 200$ have known cognate agonists and the larger part are still "orphan," i.e., without yet identified agonists (Vassilatis et al., 2003). Evaluation of GPCR expression in vivo has been largely hampered by lack of specific antibodies against this class of receptors. Thus, over the years, microarray technology allowed researchers to monitor the mRNA expression levels of thousands of GPCRs encoding genes. Based on the available genomic data (Hakak et al., 2003; Katugampola and Davenport, 2003; Tang and Insel, 2004; Regard et al., 2008; Moore-Morris et al., 2009), we tried to summarize the different GPCRs detected in the whole cardiac tissue (cardiomyocytes, endothelial cells, fibroblasts...) (Table 2), their classical G protein coupling and a selective agonist/antagonist for most of them. This list is non-exhaustive and selectivity or description of these compounds will not be detailed here. Thus, selective pharmacological targeting of Gaior Gas-coupled cardiac receptors represents a way to modulate intracellular cAMP levels. It is noteworthy that the classical GPCR coupling has to be enlarged as a recent study shows dual agonist occupancy of the AT1-R and $\alpha 2 \mathrm{C}-\mathrm{AR}$ heterodimer, two GPCRs known to be coupled to G $\alpha \mathrm{q}$ and $\mathrm{G} \alpha \mathrm{i}$, respectively, created an original conformation different from the active individual protomers and triggered an atypical Gs/cAMP/PKA signaling (Bellot et al., 2015). Thus, co-stimulation or bivalent ligand development might be a new pharmacological area to regulate cAMP signaling (Berque-Bestel et al., 2008; Lezoualc'h et al., 2009).

\section{G $\alpha$ activators}

Cholera toxin (CTX) is a specific Gas potent activator secreted by the bacteria Vibrio cholerae which catalyzed the ADP-ribosylation of the Gas proteins. The ADP-ribosylation blocks the Gas catalytic activity and thus prevents the Gas subunit to hydrolyze the GTP once activated, leading to the ensuing sustained Gs and AC activity (De Haan and Hirst, 2004). CTX administration in non-ischemic or ischemic heart contributes to the genesis of arrhythmia highlighting the essential role for $G \alpha$ s in the regulation of cardiac physiology (Huang and Wong, 1989). More recently, Pasteurella multocida toxin (PMT), produced by toxigenic strains of the Gram-negative Pasteurella multocida bacteria, was identified as a potent and selective activator of $\mathrm{G} \alpha \mathrm{q}, \mathrm{G} \alpha \mathrm{i}$, and $\mathrm{G} \alpha 13$ by deamidating a glutamine residue in the switch II region of the G $\alpha$-GTPase domain (Orth et al., 2005, 2008). It was recently shown that, in vivo, PMT treatment in mice increased secretion and expression of connective tissue growth factor (CTGF) in cardiac fibroblasts to aggravate cardiac hypertrophy and fibrosis (Weise et al., 2015).

\section{G $\alpha$ inhibitors}

Basically, all $\mathrm{G} \alpha$ subunits inhibitors share a common molecular mechanism by preventing the GDP/GTP exchange on the G $\alpha$ GTPase domain. A famous specific and highly effective Gai inhibitor is Pertussis Toxin (PTX). PTX is a protein complex released by the bacterium Bordetella pertussis in an inactive form. PTX catalyzes the ADP-ribosylation of the Gai subunit of the heterotrimeric $G$ protein. The Gai subunit remains locked in its GDP-bound inactive state, thus unable to interact with the receptor and to inhibit adenylyl cyclase activity (Hsia et al., 1984; Burns, 1988). PTX-pretreatment is classically used to delineate the involvement of $\mathrm{G} \alpha \mathrm{i}$-dependent signaling. It revealed for instance an increase in $\beta$-AR dependent inotropic response and cAMP accumulation in isolated ventricular cardiomyocytes (Melsom et al., 2014), confirming the dual coupling of $\beta 2$-AR to both $G \alpha i$ and $G \alpha s$ (Xiao, 2001) in the cardiac tissue. On a purified $\mathrm{G} \alpha$ activity assay, suramin, an antimicrobial drug, was identified as a more selective inhibitor for $\mathrm{G} \alpha \mathrm{s}\left(\mathrm{IC}_{50} \approx\right.$ $250 \mathrm{nM})$ than for $\mathrm{G} \alpha \mathrm{o}\left(\mathrm{IC}_{50} \approx 2 \mu \mathrm{M}\right)$ or $\mathrm{G} \alpha \mathrm{i}\left(\mathrm{IC}_{50} \approx 5 \mu \mathrm{M}\right)$. Suramin exerts its effects by binding the effectors binding site on the $\mathrm{G} \alpha$ proteins (Freissmuth et al., 1996). It has to be noted that suramin is a large highly sulfonated and negatively charged molecule that limits its use to in vitro studies as it cannot cross the cell plasma membrane. Hohenegger and coworkers worked on suramin derivatives to increase specificity toward Gas and identified two compounds (NF449 and NF503) that suppress the Gas activation coupled to $\beta$-adrenergic receptors,

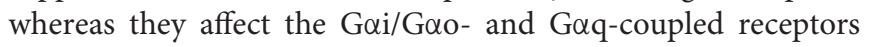


TABLE 2 | GPCR expressed in heart: G $\alpha$ coupling and pharmacological way to modulate their signaling.

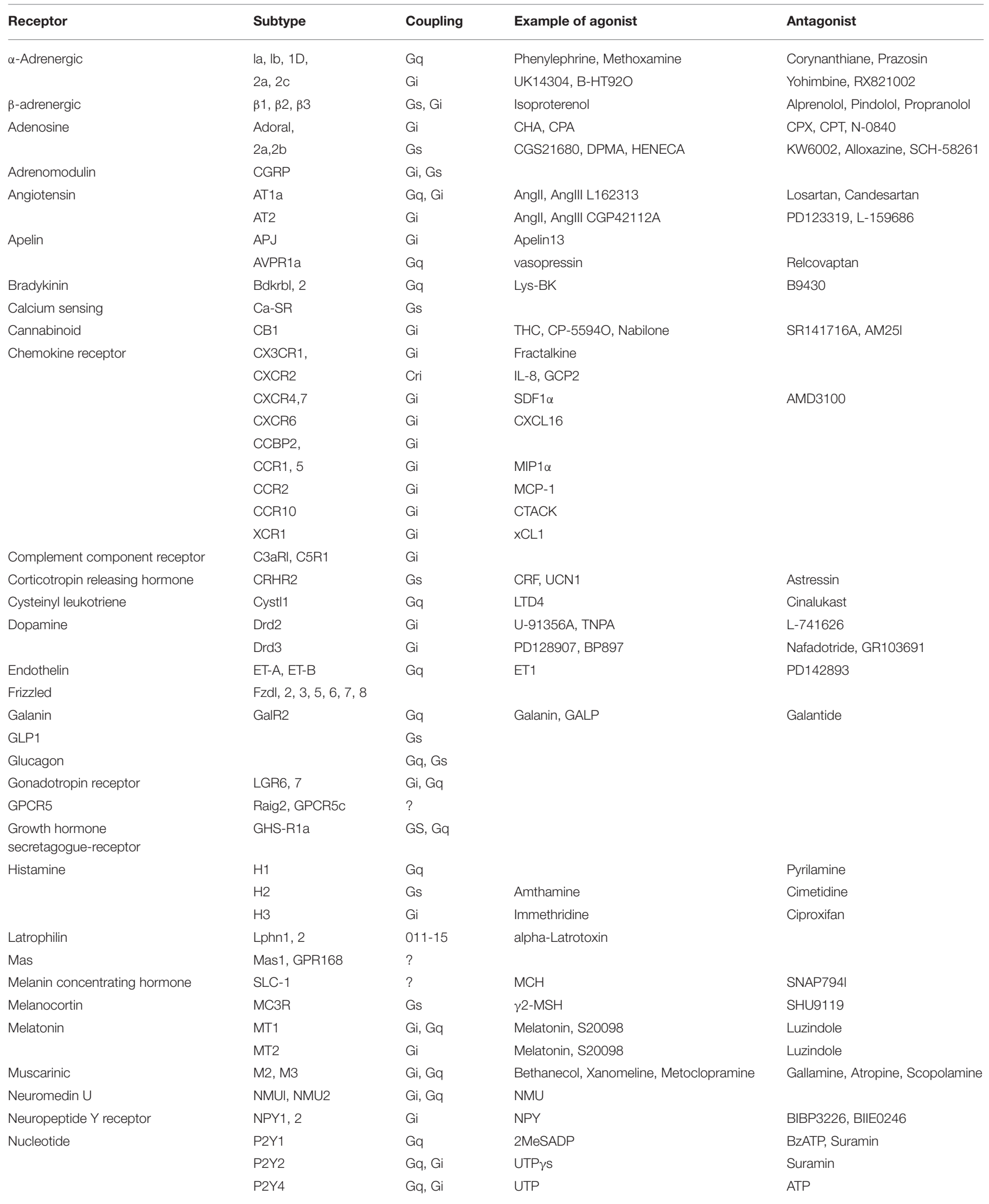


TABLE 2 | Continued

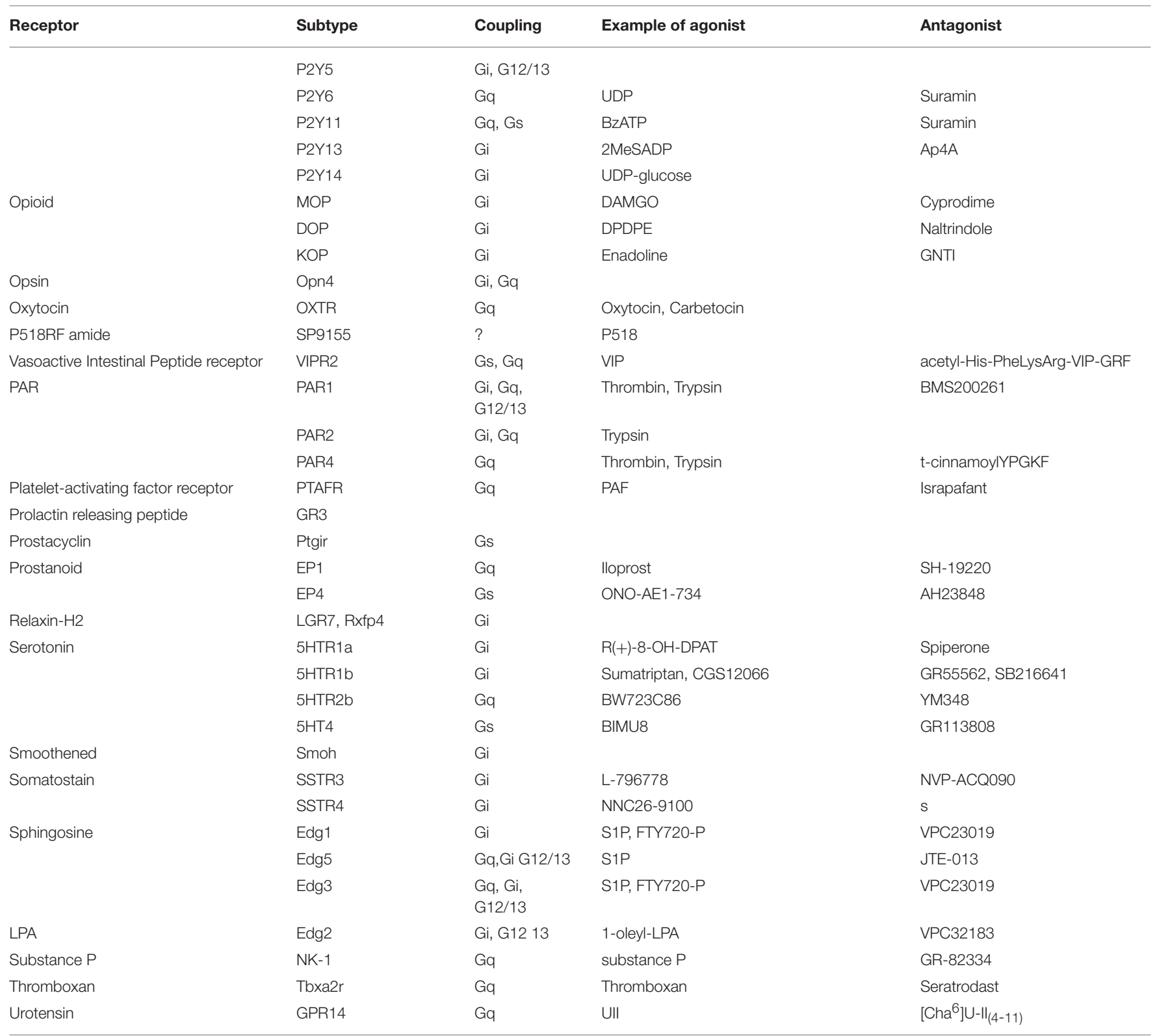

Other GPCR expressed in Heart

\begin{tabular}{ll}
\hline CD97 & GPR77(C5L2) \\
ELTD1 & GPR82 \\
EMR1 & GPR107 \\
TM7SF3 & GPR108 \\
GPR1 & GPR116 \\
GPR10 & GPR120 \\
GPR17 & GPR124 \\
GPR21 & GPR125 \\
GPR22 & GPR133 \\
GPR27 & GPR135 \\
GPR30 & GPR137 \\
GPR31 & GPR137b
\end{tabular}


TABLE 2 | Continued

Other GPCR expressed in Heart

\begin{tabular}{ll}
\hline GPR34 & GPR146 \\
GPR4 & GPR153 \\
GPR44 & GPR161 \\
GPR48 & GPR175 \\
GPR54 & GPR182 \\
GPR56 & GPR183 (Ebi2)
\end{tabular}

This table summarized the list of mRNA encoding for GPCRs detected in the whole cardiac tissue (cardiomyocytes, endothelial cells, fibroblasts...) extracted from (Hakak et al., 2003; Katugampola and Davenport, 2003; Tang and Insel, 2004; Regard et al., 2008; Moore-Morris et al., 2009), the main known Ga protein coupling, an example of an agonist and an antagonist (this list is non-exhaustive and selectivity for each molecule is not discussed).

(A1-adenosine and angiotensin II receptor, respectively) to a much lesser extent (Hohenegger et al., 1998). Lately, BIM-46174 and BIM-46187 were classified and used as pan $\mathrm{G} \alpha$ inhibitors

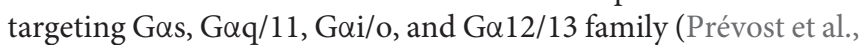
2006). However, these cell permeable compounds have not be tested toward all the individual members of $\mathrm{G} \alpha$ subunit family and more recently Kostenis and colleagues found that BIM-46187 was more selective to inhibit $\mathrm{G} \alpha \mathrm{q}$ depending on the cellular context (Schmitz et al., 2014).

\section{G $\beta \gamma$ complex inhibitors}

Smrcka and coworkers described small molecule G $\beta \gamma$ inhibitors that selectively block $G \beta \gamma$-binding interactions to their effectors, including M119 and its highly related analog, gallein (Lehmann et al., 2008). These compounds blocked interaction of $G \beta \gamma$ and GRK2 in vitro and reduced $\beta$-AR-mediated membrane recruitment of GRK2 in isolated adult mouse cardiomyocytes (Casey et al., 2010). The authors showed M119 enhanced both adenylyl cyclase activity and cardiomyocyte contractility in response to $\beta$-AR agonist (Casey et al., 2010). More recently, in a screen for the identification of OXE receptor antagonists, Gue1654 was discovered as a biased inhibitor that selectively prevent $G \beta \gamma$ signaling without affecting the $G \alpha$ pathway (Blättermann et al., 2012). The molecular mechanism underlying Gue1654 action is still under investigation.

\section{Targeting Tyrosine Kinase Receptor Signaling}

It has to be noted that $\mathrm{AC}$ have been involved in the mechanisms of action of insulin and other peptides of the insulin superfamily like Insulin-like Growth factor I, relaxin and mollusc insulin-like peptide which are ligands for tyrosine kinase receptors (TKR) (Pertseva et al., 2003). Earlier, it was shown that in the heart EGF, another TKR, triggered some AC mediated effect (Nair and Patel, 1993). At a molecular level, TKR dependent activation of AC can rely on the activation of PI3K, PKC $\zeta$, or the G $\beta \gamma$ complex (Wilson et al., 1996; Standaert et al., 1997; Molina-Munoz et al., 2006). Thus, modulating activities of TKRs and their signaling regulators constitute an alternative approach to modulate cAMP but such compounds will not be described in this review.

\section{Modulation of cAMP Degradation Phosphodiesterases Inhibitors}

The cardiostimulatory action of PDE make their inhibition as a promising therapeutic approach for the treatment of heart failure by sustaining cAMP production and action. Methylated xanthines, like theophylline, caffeine, or Iso-butylmethyl-xanthyl (IBMX), are long known to act as competitive nonselective PDE inhibitors (Hess et al., 1975) but they also exhibit nonselective PDE action like adenosine receptor antagonist activities (Ukena et al., 1986). Over the years, several more specific and selective PDEs inhibitors have been developed. Representative selective inhibitors that can be used in cardiac tissue are listed below. Originally, 8-MM-IBMX was thought to be PDE1 selective (Rybalkin et al., 2002), but an extensive in vitro study characterized more potent and more selective compounds able to inhibit PDE1 activity like SCH51866 (Dunkern and Hatzelmann, 2007). The first specific inhibitor developed for PDE2 was EHNA [erythro-9-(2-hydroxy-3-nonyl)adenine] with an IC50 value of $\sim 1 \mu \mathrm{M}$ (Podzuweit et al., 1993) but a screen of compounds developed by Bayer showed that BAY60-7550 (an EHNA analog) was 100-fold more potent and 50-fold more selective for PDE2A over other PDEs compared to EHNA (Boess et al., 2004). Cilostamide-dependent PDE inhibition was discovered in 1970's (Hidaka et al., 1979) but cilostamide and its derivative selectivity for PDE3 family was described by Sudo et al. (2000). The prototypical PDE4 inhibitor is rolipram; originally named ZK62711, that was discovered in 1976 (Schwabe et al., 1976) but its use was limited by its associated side effects, particularly those affecting the gastrointestinal tract (Barnette and Underwood, 2000). Thus, in 2010, potency and selectivity of roflumilast and its active metabolite have been studied for all PDE (Hatzelmann et al., 2010). Roflumilast does not affect PDE enzymes apart from PDE4 family, and has a subnanomolar inhibitor activity toward all PDE4 splicing variants tested (Rabe, 2011). As the PDE4 family is encoded by 4 genes (PDE4A, $\mathrm{B}, \mathrm{C}$, or D) and 27 splice variants, identification of selective PDE4 subtypes inhibitors has been boosted and especially for PDE4B that can be selectively inhibited for example by triazine derivative (Hagen et al., 2014). ASB16165 was characterized as a specific and highly potent inhibitor for PDE7A with an IC50 value of $15 \mathrm{nM}$ for human PDE7A (Kadoshima-Yamaoka et al., 2009). PDE8s are inhibited by dipyridamole, despite this drug is also known as a relatively nonselective cGMP specific PDE5 inhibitor (Soderling et al., 1998) while two studies have described a newly available PDE8 inhibitor developed by Pfizer, PF-04957325 (Vang et al., 2010; Shimizu-Albergine et al., 2012). 


\section{Cyclic Nucleotide Efflux Transporters: Description and Inhibitors}

As mentioned earlier, ABCC [ATP-binding cassette (ABC) transporter superfamily (subfamily $\mathrm{C}$ )] regulates cAMP efflux into the extracellular space to decrease cAMP availability. Three of them (ABCC4, $\mathrm{ABCC} 5$, and $\mathrm{ABCC} 11)$ are expressed in cardiac tissue but $\mathrm{ABCC} 4$ is the most studied and has been shown to enhance cAMP formation, contractility, and cardiac hypertrophy (Sassi et al., 2012). Non selective inhibitors including MK-571, dipyrimamole or indomethacin (Reid et al., 2003) have been described to dually inhibit ABCC transporters and PDEs (Xie et al., 2011). Thus, the interpretation of experiments using those compounds has to take in account their side activities. In 2014, a high throughput screening identified Ceefourin 1 and 2 as highly selective ABCC4 inhibitors (Cheung et al., 2014). The authors described a micromolar inhibition of ABCC4 over other members of ABCC transporter families but no data are available concerning their effect on PDE activity (Cheung et al., 2014).

\section{Optogenetics Methods to Modulate cAMP Availability}

The genome of Beggiatoa, a sulfide-oxidizing bacterium, revealed the presence of a DNA sequence encoding for a cytosolic adenylyl cyclase directly linked to a BLUF (blue light receptor using FAD) type light sensor domain. This photoactivatatable adenylyl cyclase (bPAC) shows a low cyclase activity in the dark but that increases about 300-fold upon light activation (Stierl et al., 2011). Efetova et al. pioneered the use of bPAC to distinguish between the functions of alternative cAMP effectors in the in vivo regulation of a Drosophila melanogaster physiological process (Efetova et al., 2013) while Von Zastrow's group recently used the bPAC fused to different targeting sequences to assess the role of cAMP compartmentation in GPCR signaling (Tsvetanova and von Zastrow, 2014). Recently, a red light-activated PDE was engineered by recombining the photosensor module of Deinococcus radiodurans bacterial phytochrome with the effector module of Homo sapiens PDE2A (Gasser et al., 2014). Compare to the bPAC system, the red-shifted activation of this new tool will allow the creation of interesting animal model to study the spatio-temporal cAMP signaling pathway. This concept was declined for multiple targets referenced and collected by the CHROMus project (Shui et al., 2014) and applied to GPCR where the cytosolic part of the Rhodopsin receptor was replaced by the $\beta 2$-AR receptor part to create a photoactivable G $\alpha$ s coupled GPCR (Airan et al., 2009).

\section{Modulation of cAMP Effectors}

cAMP has four direct intracellular targets: protein kinase A (PKA), the exchange protein activated by cAMP (EPAC), the cyclic nucleotide gated ion channels (CNGC) and the popeye domain containing protein (POPDC). cAMP output signaling can be modulated by targeting its effectors.

\section{PKA Inhibitors and Activators}

Inactive PKA relies on an heterotretamer consisting of two regulatory $(\mathrm{R})$ and two catalytic $(\mathrm{C})$ subunits (Figure 3A). Two principal isoforms of the R-subunit (type I and II) each further subclassified into $\alpha$ and $\beta$ subtypes (Hofmann et al., 1975) and three isoforms of the C-subunit have been described in mammals $(\mathrm{C} \alpha, \mathrm{C} \beta$, and C $\gamma$ ) (Uhler et al., 1986; Beebe et al., 1990). RII $\alpha$ is the major isoform expressed in the heart but can also be found in the brain (Skalhegg and Tasken, 2000). RI $\alpha$ is also expressed in the cardiac tissue and the central nervous system while RI $\beta$ and RII $\beta$ are respectively found in the spinal cord or brain and liver or fat tissue (reviewed in Skalhegg and Tasken, 2000). In regard to its molecular mechanism of activation, two cAMP molecules bind to each R-subunit and induce a conformational rearrangement of PKA which initiates the functional dissociation of the regulatory from the catalytic subunits (Murray, 2008).

The classically used PKA inhibitors, H89 (isoquinolone derivative) and KT5720 (synthesized from fungus Nocardiopsis sp.) act as competitive antagonists of the cAMP nucleotide for the binding site on the PKA regulatory subunit (Kase et al., 1987; Engh et al., 1996). Studying the specificity for commonly used inhibitors for a range of protein kinases, Davies and coworkers found unspecific effect for H89 and KT5720 as they were found to inhibit other kinases at lower concentrations than those used to prevent PKA activation (Davies et al., 2000). For instance, $\mathrm{H} 89$ is able to inhibit ROCK, $66 \mathrm{~K}, \mathrm{PKB} \alpha$, or MSK1 while KT5720 inhibits PDK1 and PHK (Davies et al., 2000). Alternate PKA inhibitors were developed including Rp-cAMPs and its derivatives. Those inhibitors act as competitive antagonists of the cyclic nucleotide binding domain on the regulatory PKA subunit. A study in Dictyostelium has characterized both selectivity and degradation of such compounds (Schaap et al., 1993) and demonstrated that those molecules can indeed inhibit proteins containing other cAMP binding domain. Finally, the protein kinase inhibitor peptide (PKI) remains likely the most specific way to interfere with PKA as it binds to the free catalytic subunit and prevents phosphorylation of PKA targets (Dalton and Dewey, 2006). However, high concentration of this peptide can also inhibit PKG signaling (Glass et al., 1992). By opposition to PKA inhibitors, 8pcpt-cAMP and its derivative (Sp-5,6-DClcBiMPS) are cell permeable cAMP analogs that can bind the PKA-cAMP binding site and promote the activation of PKA downstream effectors (Sandberg et al., 1991).

\section{Epac Inhibitors and Activators}

Epac (exchange protein activated by cAMP) constitutes with PKA the main direct cAMP effector and has been identified by two independent group in 1998 (de Rooij et al., 1998; Kawasaki et al., 1998). In mammals, two isoforms of Epac (Epac1 and Epac2), products of independent genes have been identified which contain a cAMP binding domain (that is homologous to that of PKA R subunits) and other conserved domains (Figure 3B). Its activation relies on a conformational rearrangement of the protein promoted by cAMP binding. Epac1 is mostly abundant in the heart, kidney, blood vessels, adipose tissue, central nervous system, ovary, and uterus, whereas Epac2 splice variants (Epac2A and Epac2B) are mostly expressed in the central nervous system (Epac2A), adrenal gland (Epac2B), and pancreas (Epac2A) (de Rooij et al., 1998; Kawasaki et al., 1998; Niimura et al., 2009). Once activated, Epac proteins activate the Ras superfamily small G proteins Rap1 and Rap2 (for review Cheng et al., 


\section{A}

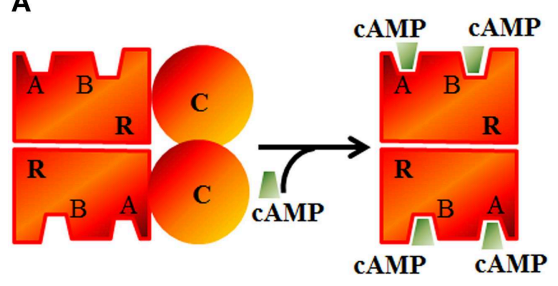

B

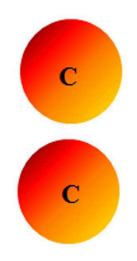

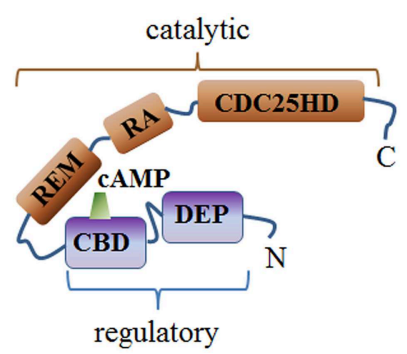

FIGURE 3 | Schematic structure of PKA and EPAC. (A) The catalytic (c) subunit of cAMP-dependent Protein Kinase (PKA) is a serine/threonine protein kinase associated, in the absence of cAMP, with the regulatory $(\mathrm{R})$ subunit to form the inactive PKA holoenzyme. cAMP can bind to A or B sites in the regulatory subunits and induces the dissociation of the catalytic subunits. (B) Epac structure showing the conserved cAMP binding domain (CBD), Disheveled/Egl-10/pleckstrin (DEP) domain, RAS exchange motif (REM) domain, RAS association (RA) domain, and CDC25-homology domain (CDC25HD).

2008) by functioning as guanine nucleotide exchange factors. In cardiomyocytes, Epac proteins are involved in the formation of gap junctions to coordinate cardiac contractions through gating ions and small molecules (Somekawa et al., 2005) and enhances intracellular $\mathrm{Ca}^{2+}$ release during cardiac excitation-contraction coupling (Pereira et al., 2007). A High throughput screening assay to identify Epac inhibitors without affecting PKA activity led Cheng and coworkers to the identification of ESI-05 as an isoform specific inhibitor of Epac2 but not Epac1 (Tsalkova et al., 2012) and ESI-09 an pan inhibitor of Epac1 and 2 (Almahariq et al., 2013). CE3F4 compound (Courilleau et al., 2012) was identified as a specific Epac1 inhibitor without influence on PKA activity and its isoform selectivity for EPAC1 toward EPAC2 was demonstrated later (Courilleau et al., 2013). CE3F4 could be of interest in the therapeutic of cardiac pathophysiology as Epac1 is involved in $\beta$-adrenergic receptor-induced cardiomyocyte hypertrophy (Métrich et al., 2008). The compound usually named 007 [8-(4-Chloro-phenylthio)-2'-O-methyl-cAMP] is a cAMP analog activating Epac but not PKA (Enserink et al., 2002) but it has to be noted that 007 can behave as an inhibitor of PDEs which may indirectly increases cyclic nucleotide concentration (Poppe et al., 2008).

\section{CNGC Inhibitors}

The family of cyclic nucleotide gated channels (CNGC) comprises two groups: cyclic nucleotide gated (CNG) channels and the hyperpolarization-activated cyclic nucleotidegated $(\mathrm{HCN})$ channels. Both types are members of the six transmembrane channel superfamily and contain a cyclic nucleotide binding domain in their cytosolic C-Terminus that serves as an activation domain. Upon cyclic nucleotide binding, CNG channels gates the flow of monovalent cations such as $\mathrm{Na}^{+}$and $\mathrm{K}^{+}$to cross the plasma membrane and have a greater sensitivity for cGMP than for cAMP (for review Podda and Grassi, 2014). HCN cations channels open upon hyperpolarization and cAMP enhance their activity by shifting the activation curve to more positive voltage (Scicchitano et al., 2012). Four members exist in mammals (HCN1-HCN4) and are known to regulate the If current to control heart rate and rhythm by acting as a pacemaker current in the sinoatrial node (Wahl-Schott et al., 2014). If current is regulated by various neurotransmitters and metabolic stimuli (Pape, 1996) and are promising pharmacological targets in the treatment of cardiac arrhythmias. Thus, the most extensively studied HCN channels blocker is ZD7288 (BoSmith et al., 1993) but If current can also be blocked by ivabradine (Bucchi et al., 2002, 2006), zatebradine, and cilobradine (Van Bogaert and Pittoors, 2003). Ivabradine derivatives led to the discovery of HCN selective blockers with EC18 identified as a selective blocker for HCN4 and MEL57A induced mHCN1 inhibition (Melchiorre et al., 2010; Del Lungo et al., 2012).

\section{POPDC Inhibitor}

The Popeye domain-containing gene family consists of 3 genes (podc1, podc2, and popdc3) encoding a 3 transmembrane proteins that bind cAMP through their conserved cytoplasmic Popeye domain with an affinity ( $\mathrm{IC}_{50}$ ) of $120 \mathrm{nM}$, which is comparable to the affinities reported for PKA (100 nM) (Froese et al., 2012). These proteins are essential for stress mediated modulation of cardiac pacemaking (Froese et al., 2012; Schindler et al., 2012). To our knowledge, no pharmacological inhibitors have been reported to investigate specific POPDC protein function so that the only way to modulate their activities so far is the use of genetic tools (small interfering RNA technology or gene knockout).

\section{Methods for CAMP Detection in the Cardiac Tissue}

The number of technologies that enables the functional screening of cAMP production has expanded over the years. Consequently, the choice of the technology will define the scope of the conclusions that can be drawn. Those methods can be divided into two groups: the direct methods allowing an "absolute" cAMP concentration quantification and the indirect methods which give a relative representation of cAMP availability. Thus, as summarized in Table 3, direct methods are generally more sensitive than indirect one since lacking any mediator but cannot accurately sense low cAMP levels produced in subcellular compartments. The advantages and limits of the common systems are listed below and basic principle for each technique is shown on Table 3. As previously pinpointed, cAMP availability is 
TABLE 3 | Comparison of cAMP detection system.

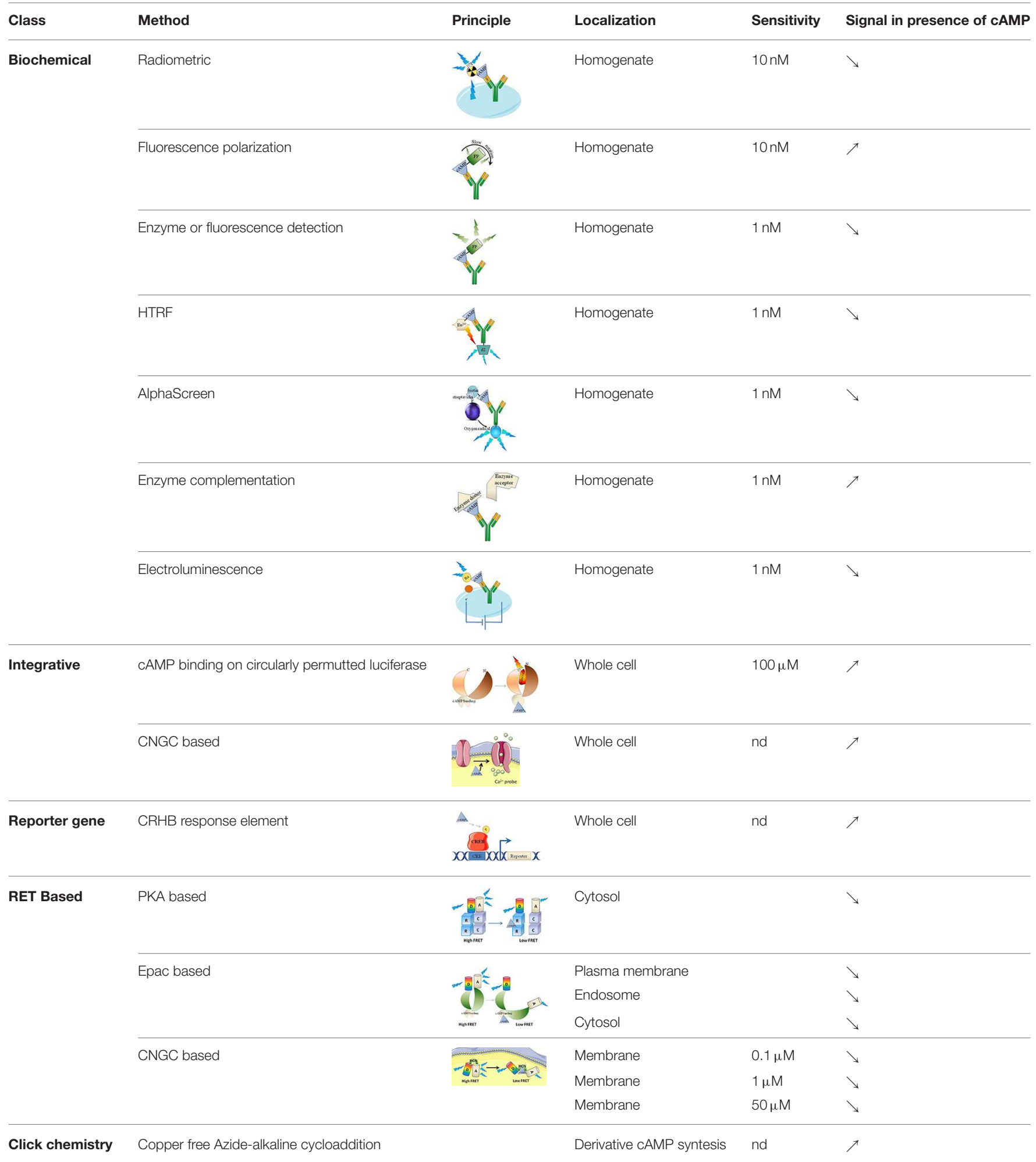

fine-tuned by a tight balance between its synthesis and immediate hydrolysis/efflux/use so that at one time point, cAMP is not enough amenable to quantification assays. Thus, accumulation of cAMP is often mandatory in most of cAMP detection assays with the common use of the pan PDEs inhibitor IBMX (when cAMP production needs to be measured) or FSK pretreatment 
(when cAMP production inhibitory function wants to be outlined).

\section{Direct Methods: Biochemical Approaches}

cAMP has been long quantified through a radioactive functional assay based on affinity chromatography purification using ${ }^{3} \mathrm{H}$ ATP-preloaded cells lysates. After lysis and cAMP production can be estimated by measuring the ratio between ${ }^{3} \mathrm{H}$-cAMP over ${ }^{3} \mathrm{H}$ ATP $+{ }^{3} \mathrm{H}$-cAMP separated on affinity column (Piñeyro et al., 2005). Despite its high sensitivity, this technique often requires the presence of PDEs inhibitor and is not suitable for high throughput screening (HTS) strategy. Most of HTS biochemical methods relies on the general principle that cAMP accumulation is being detected by competition for a specific cAMP antibody between free unlabelled cAMP present in the sample to evaluate and a labeled form (radioactive, fluorescent, or enzymatic) of cAMP (Williams, 2004). Radiometric assays allow detection of cAMP using competition with ${ }^{125-}$ I labeled cAMP for anticAMP antibody immobilized on a solid scintillant plate. In those assays, the radiometric signal decreases proportionally to the amount of cAMP present in the sample (Horton and Baxendale, 1995). Fluorescence polarization cAMP assays monitor the light emitted from a fluorescent-tagged cAMP following excitation by a polarized light source. When the labeled cAMP is bound to an antibody more polarized light will be produced upon excitation (Prystay et al., 2001; Huang et al., 2002). To increase the signal to noise and to avoid cell autofluorescence detection, Cisbio developed an HTRF (Homogeneous time resolved fluorescence)-based cAMP assay. This assay is still based on a competitive immunoassay using cryptate-labeled anticAMP antibody and d2-labeled cAMP (Degorce et al., 2009). Alpha-screen technology uses acceptor beads conjugated to an antibody that recognizes cAMP and streptavidin-coated donor beads. When brought into close proximity by the presence of biotinylated cAMP, an oxygen radical dependent light is emitted. The cAMP extracted from a cell lysate will compete with the biotinylated cAMP and reduce the emitted light. This kind of assay is also available with an enzymatic based detection method where cAMP found in test sample competes with a fixed amount of Horse Radish Peroxydase-linked cAMP for binding to an anti-cAMP immobilized antibody (Bouchard et al., 2006). The electroluminescence technique (Mesa Scale Discovery) is another competitive immunoassay based on the displacement of ruthenium-labeled cAMP for an anti-cAMP antibody. The electrochemical reaction is initiated upon substrate and electrical charge addition and produce light which is inversely proportional to the cAMP present in the sample (Filip et al., 2004). The immuno-based competition can also be revealed using an enzyme complementation method (DiscoverX). In this assay, a fragment of $\beta$-galactosidase ( $\beta$-gal) is conjugated with cAMP and act as an enzyme donor (ED) (Golla and Seethala, 2002). This ED-cAMP conjugate and cellular cAMP compete for binding to an anti-cAMP antibody. In presence of the enzyme acceptor (EA), the active enzyme will be reconstituted and will be able to subsequently hydrolyze a substrate to produce a chemiluminescent signal that is directly proportional to the amount of cAMP in the cells. Despite being sensitive and specific, all those techniques require cells or tissue disruption making the real-time and sub-cellular analysis of cAMP quantification impossible. Moreover if those assays are highly efficient to measure cAMP production, their use to bring to the fore cAMP inhibition is challenging and require FSK pretreatment.

\section{Indirect Methods \\ Integrative Methods}

Promega developed an assay based on the GloSensor Technology, a genetically modified form of firefly luciferase into which a cAMP-binding protein domain has been inserted (Fan et al., 2008). The firefly luciferase is circularly permuted and upon cAMP binding, a conformational change induces luciferase enzyme reconstitution which produces light in presence of its substrate. This technique is sensitive enough to assess role of endogenous receptors but requires transfection of the biosensor, thus limiting the quantification of the cAMP to the transfection efficiency (expression heterogeneity between cells) which can lead to high results variability. Maintaining advantages of integrative methods (sensitivity and kinetic) but avoiding transfection variability, Rivero-Müller's group developed a derived detection method CANDLES (Cyclic AMP iNdirect Detection by Light Emission from Sensor cells). Briefly, a stable cell line expressing a GloSensor plasmid is co-cultured with cells expressing the receptor to be tested and through cellcell interaction via gap junctions, cAMP produced by the cell of interest can be transferred to the sensor cells to activate GloSensor plasmid (Trehan et al., 2014). Finally, given that the GloSensor is a cytosolic probe, it could be not appropriate to detect low concentrations of compartmentalized cAMP at the plasma membrane.

\section{Reporter Gene Methods}

The reporter gene method is a homogeneous, simple and inexpensive but indirect method to detect cAMP-downstream signaling. This assay is based on the specific activation of the transcription factor CREB (cAMP response element binding protein) upon cAMP production which induces a reporter gene under the control of a CRE element (cAMP Response Element) promoter. Various reporter genes have been used over the years: fluorescent proteins, luciferase, $\beta$-galactosidase or $\beta$-lactamase. Far downstream of the cAMP activation cascade, this method is sensitive but unable to give kinetics or localization information.

\section{Resonance Energy Transfer Methods}

The methods described above are unable to define the cellular localizations of cAMP production. Thus, visualization was achieved using resonance energy transfer (RET) techniques described by the Theodor Förster in 1940's (Forster, 1946). RET is a mechanism relying on an energy transfer between a donor chromophore that may transfer energy to another acceptor chromophore through non-radiative dipole-dipole coupling upon distances proximity conditions (Hebert et al., 2006; Kiyokawa et al., 2006). The name FRET "Förster resonance energy transfer" which includes the commonly used term FRET "Fluorescence resonance energy transfer" and 
BRET "Bioluminescence resonance energy transfer" is a nonradiative transfer of energy occurring between two fluorescent chromophores for FRET or between an enzyme generating luminescent signal upon addition of its substrate and a fluorescent acceptor partner in the case of BRET technology. The efficiency of this energy transfer is inversely proportional to the sixth power of the distance between donor and acceptor, making RET extremely sensitive to very small changes in distance thus allowing an accurate sensing of change in protein conformations for instance (Hebert et al., 2006). BRET is a first line assay for HTS screening as it avoids the consequences of fluorescence excitation and has a better Stokes' shift over FRET but is not recommended for imaging technique to identify localized cAMP compartmentalization. Thus RET-based methods have been developed to detect cAMP production and extensively reviewed (Williams, 2004; Willoughby and Cooper, 2008; Sprenger and Nikolaev, 2013; Calebiro and Maiellaro, 2014). All the methods rely on the use of the downstream cAMP effectors PKA, Epac or CNGC either that all directly bind cAMP molecules related to the expression of a specific cAMP-binding motif. Briefly, either full-length cAMP-effector probes or single cAMP domain sensor extracted from the different effectors are fused to an energy donor and acceptor allowing the generation of a basal RET signal in the absence of cAMP production. Upon cAMP binding, a conformational rearrangement in the RET-based sensor will lead to a modification of the RET signal. Since the pioneering studies using those RET probes to study cAMP availability in cardiac tissue (Zaccolo et al., 2000; Zaccolo and Pozzan, 2002), many efforts have been made these last years to improve signal to noise ratio, RET efficiency (optimizing donor-acceptor couple, linker optimization), cAMP binding affinity (mutagenesis on single domain or full length protein probes), RET detection methods (e.g., Sensitized emission vs Fluorescence lifetime imaging microscopy for FRET-based probes, Renilla luciferase variants for BRET-based probes) (Willoughby and Cooper, 2008; Sprenger and Nikolaev, 2013). Moreover with the prominently recognized mechanism for cAMP compartmentation, several group restricted the expression of those RET based probes to subcellular localization using for example plasma membrane targeting sequence or endosome localization (Klarenbeek and Jalink, 2014; Sprenger et al., 2015).

\section{Copper Free Azide-alkaline Cycloaddition: a "Click Chemistry"}

In chemical synthesis, click chemistry is a process that generates by joining small units together. The azide alkyne Huisgen cycloaddition using a Copper $(\mathrm{Cu})$ catalyst is one of the most popular reactions within the Click chemistry concept between an azide and a terminal or internal alkyne to give a 1,2,3-triazole (Rostovtsev et al., 2002; Tornøe et al., 2002). To avoid Cu toxicity, Baskin et al. developed a $\mathrm{Cu}$-free click reaction with comparable kinetics to $\mathrm{Cu}$ dependent cycloaddition, but adapted for dynamic in vivo imaging (Baskin et al., 2007). In a recent study, this copper free method was applied to detect cAMP derivative (8-azido cAMP) in vivo after the addition of difluorinated cyclooctyne (DIFO) as a reagent (Ito et al., 2013). If this approach will enable to visualize and quantify derivative cAMP endogenous modulators at the single cell level without exogenous transfection protocol, it has to be noted that the molecule used is a cAMP derivative so the signal observed will be the result of

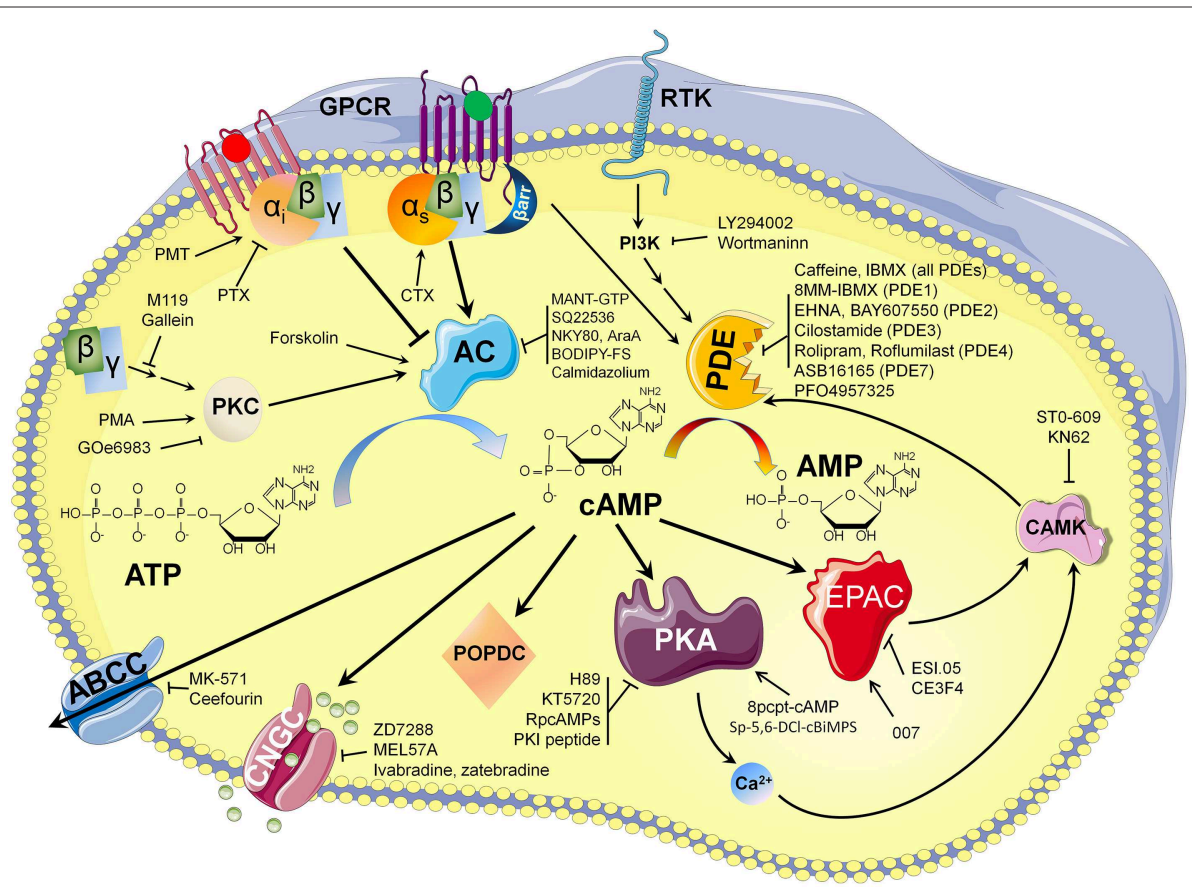

FIGURE 4 | CAMP synthesis and hydrolysis: pharmacological way to modulate its availability. 
ACs/PDEs activities in competition with cAMP endogenously produced.

\section{Conclusion}

The development of optical methods that allow monitoring of cAMP dependent signaling in living cells and the growing list of molecules (summarized in Figure 4) available to modulate cAMP availability played a fundamental role in revealing an unexpected level of cAMP organization in cardiac tissue. It is likely that new optical methods development, with higher temporal

\section{References}

Airan, R. D., Thompson, K. R., Fenno, L. E., Bernstein, H., and Deisseroth, K. (2009). Temporally precise in vivo control of intracellular signalling. Nature 458, 1025-1029. doi: 10.1038/nature07926

Almahariq, M., Tsalkova, T., Mei, F. C., Chen, H., Zhou, J., Sastry, S. K., et al. (2013). A novel EPAC-specific inhibitor suppresses pancreatic cancer cell migration and invasion. Mol. Pharmacol. 83, 122-128. doi: 10.1124/mol.112.080689

Anderson, M. E., Brown, J. H., and Bers, D. M. (2011). CaMKII in myocardial hypertrophy and heart failure. J. Mol. Cell. Cardiol. 51, 468-473. doi: 10.1016/j.yjmcc.2011.01.012

Asirvatham, A. L., Galligan, S. G., Schillace, R. V., Davey, M. P., Vasta, V., Beavo, J. A., et al. (2004). A-kinase anchoring proteins interact with phosphodiesterases in T lymphocyte cell lines. J. Immunol. 173, 4806-4814. doi: 10.4049/jimmunol.173.8.4806

Baillie, G. S. (2009). Compartmentalized signalling: spatial regulation of cAMP by the action of compartmentalized phosphodiesterases. FEBS J. 276, 1790-1799. doi: 10.1111/j.1742-4658.2009.06926.x

Baker, A. J. (2014). Adrenergic signaling in heart failure: a balance of toxic and protective effects. Pflugers Arch. 466, 1139-1150. doi: 10.1007/s00424-0141491-5

Barnette, M. S., and Underwood, D. C. (2000). New phosphodiesterase inhibitors as therapeutics for the treatment of chronic lung disease. Curr. Opin. Pulm. Med. 6, 164-169. doi: 10.1097/00063198-200003000-00014

Baskin, J. M., Prescher, J. A., Laughlin, S. T., Agard, N. J., Chang, P. V., Miller, I. A., et al. (2007). Copper-free click chemistry for dynamic in vivo imaging. Proc. Natl. Acad. Sci. U.S.A. 104, 16793-16797. doi: 10.1073/pnas.0707090104

Beavo, J. A., and Brunton, L. L. (2002). Cyclic nucleotide research - still expanding after half a century. Nat. Rev. Mol. Cell Biol. 3, 710-718. doi: 10.1038/ nrm911

Beebe, S. J., Oyen, O., Sandberg, M., Froysa, A., Hansson, V., and Jahnsen, T. (1990). Molecular cloning of a tissue-specific protein kinase (C gamma) from human testis-representing a third isoform for the catalytic subunit of cAMPdependent protein kinase. Mol. Endocrinol. 4, 465-475. doi: 10.1210/mend-43-465

Bellot, M., Galandrin, S., Boularan, C., Matthies, H. J., Despas, F., Denis, C., et al. (2015). Dual agonist occupancy of AT1-R-alpha2C-AR heterodimers results in atypical Gs-PKA signaling. Nat. Chem. Biol. 11, 271-279. doi: 10.1038/nchembio.1766

Berque-Bestel, I., Lezoualc'h, F., and Jockers, R. (2008). Bivalent ligands as specific pharmacological tools for $G$ protein-coupled receptor dimers. Curr. Drug Discov. Technol. 5, 312-318. doi: 10.2174/157016308786733591

Bers, D. M. (2008). Calcium cycling and signaling in cardiac myocytes. Annu. Rev. Physiol. 70, 23-49. doi: 10.1146/annurev.physiol.70.113006.100455

Blättermann, S., Peters, L., Ottersbach, P. A., Bock, A., Konya, V., Weaver, C. D., et al. (2012). A biased ligand for OXE-R uncouples Galpha and Gbetagamma signaling within a heterotrimer. Nat. Chem. Biol. 8, 631-638. doi: 10.1038/nchembio.962

Boess, F. G., Hendrix, M., van der Staay, F. J., Erb, C., Schreiber, R., van Staveren, W., et al. (2004). Inhibition of phosphodiesterase 2 increases neuronal cGMP, synaptic plasticity and memory performance. Neuropharmacology 47, 1081-1092. doi: 10.1016/j.neuropharm.2004.07.040 and spatial resolution, will improve our knowledge of cAMP dependent signaling microdomains located on the cell surface or other intracellular membranes for individual cells within heart architecture.

\section{Funding}

This work was supported and funded by "Fondation Bettencourt Schueller and Institut National de la santé et de la Recherche Médicale."

Böl, G. F., Gros, C., Hulster, A., Bösel, A., and Pfeuffer, T. (1997). Phorbol esterinduced sensitisation of adenylyl cyclase type II is related to phosphorylation of threonine 1057. Biochem. Biophys. Res. Commun. 237, 251-256. doi: 10.1006/bbrc. 1997.7123

BoSmith, R. E., Briggs, I., and Sturgess, N. C. (1993). Inhibitory actions of ZENECA ZD7288 on whole-cell hyperpolarization activated inward current (If) in guinea-pig dissociated sinoatrial node cells. Br. J. Pharmacol. 110, 343-349. doi: 10.1111/j.1476-5381.1993.tb13815.x

Bouchard, N., Robitaille, E., and Wenham, D. (2006). cAMP AlphaScreen Assay: A Method for the Pharmacological Characterization and Screening of Gi-Coupled Receptors in Whole Cells. Waltham, MA: Perkin Elmer Application Note.

Brodde, O. E. (1993). Beta-adrenoceptors in cardiac disease. Pharmacol. Ther. 60, 405-430. doi: 10.1016/0163-7258(93)90030-H

Brunton, L. L., Hayes, J. S., and Mayer, S. E. (1981). Functional compartmentation of cyclic AMP and protein kinase in heart. Adv. Cyclic Nucleotide Res. 14, 391-397.

Bruss, M. D., Richter, W., Horner, K., Jin, S. L., and Conti, M. (2008). Critical role of PDE4D in beta2-adrenoceptor-dependent cAMP signaling in mouse embryonic fibroblasts. J. Biol. Chem. 283, 22430-22442. doi: 10.1074/jbc.M803306200

Bucchi, A., Baruscotti, M., and DiFrancesco, D. (2002). Current-dependent block of rabbit sino-atrial node I(f) channels by ivabradine. J. Gen. Physiol. 120, 1-13. doi: 10.1085/jgp.20028593

Bucchi, A., Tognati, A., Milanesi, R., Baruscotti, M., and DiFrancesco, D. (2006). Properties of ivabradine-induced block of $\mathrm{HCN} 1$ and $\mathrm{HCN} 4$ pacemaker channels. J. Physiol. (Lond). 572, 335-346. doi: 10.1113/jphysiol.2005.100776

Burns, D. L. (1988). Subunit structure and enzymic activity of pertussis toxin. Microbiol. Sci. 5, 285-287.

Calebiro, D., and Maiellaro, I. (2014). cAMP signaling microdomains and their observation by optical methods. Front. Cell. Neurosci. 8:350. doi: 10.3389/fncel.2014.00350

Casey, L. M., Pistner, A. R., Belmonte, S. L., Migdalovich, D., Stolpnik, O., Nwakanma, F. E., et al. (2010). Small molecule disruption of G beta gamma signaling inhibits the progression of heart failure. Circ. Res. 107, 532-539. doi: 10.1161/CIRCRESAHA.110.217075

Cheepala, S., Hulot, J. S., Morgan, J. A., Sassi, Y., Zhang, W., Naren, A. P., et al. (2013). Cyclic nucleotide compartmentalization: contributions of phosphodiesterases and ATP-binding cassette transporters. Annu. Rev. Pharmacol. Toxicol. 53, 231-253. doi: 10.1146/annurev-pharmtox-010611134609

Cheng, X., Ji, Z., Tsalkova, T., and Mei, F. (2008). Epac and PKA: a tale of two intracellular cAMP receptors. Acta Biochim. Biophys. Sin. (Shanghai). 40, 651-662. doi: 10.1111/j.1745-7270.2008.00438.x

Cheung, L., Flemming, C. L., Watt, F., Masada, N., Yu, D. M., Huynh, T., et al. (2014). High-throughput screening identifies Ceefourin 1 and Ceefourin 2 as highly selective inhibitors of multidrug resistance protein 4 (MRP4). Biochem. Pharmacol. 91, 97-108. doi: 10.1016/j.bcp.2014.05.023

Courilleau, D., Bisserier, M., Jullian, J. C., Lucas, A., Bouyssou, P., Fischmeister, R., et al. (2012). Identification of a tetrahydroquinoline analog as a pharmacological inhibitor of the cAMP-binding protein Epac. J. Biol. Chem. 287, 44192-44202. doi: 10.1074/jbc.M112.422956

Courilleau, D., Bouyssou, P., Fischmeister, R., Lezoualch, F., and Blondeau, J. P. (2013). The (R)-enantiomer of CE3F4 is a preferential inhibitor of 
human exchange protein directly activated by cyclic AMP isoform 1 (Epac1). Biochem. Biophys. Res. Commun. 440, 443-448. doi: 10.1016/j.bbrc.2013. 09.107

Dalton, G. D., and Dewey, W. L. (2006). Protein kinase inhibitor peptide (PKI): a family of endogenous neuropeptides that modulate neuronal cAMP-dependent protein kinase function. Neuropeptides 40, 23-34. doi: 10.1016/j.npep.2005.10.002

Davies, S. P., Reddy, H., Caivano, M., and Cohen, P. (2000). Specificity and mechanism of action of some commonly used protein kinase inhibitors. Biochem. J. 351, 95-105. doi: 10.1042/bj3510095

Defer, N., Best-Belpomme, M., and Hanoune, J. (2000). Tissue specificity and physiological relevance of various isoforms of adenylyl cyclase. American journal of physiology. Ren. Physiol. 279, F400-F416.

Degorce, F., Card, A., Soh, S., Trinquet, E., Knapik, G. P., and Xie, B. (2009). HTRF: a technology tailored for drug discovery-a review of theoretical aspects and recent applications. Curr. Chem. Genomics 3, 22-32. doi: $10.2174 / 1875397300903010022$

De Haan, L., and Hirst, T. R. (2004). Cholera toxin: a paradigm for multi-functional engagement of cellular mechanisms (Review). Mol. Membr. Biol. 21, 77-92. doi: $10.1080 / 09687680410001663267$

Del Lungo, M., Melchiorre, M., Guandalini, L., Sartiani, L., Mugelli, A., Koncz, I., et al. (2012). Novel blockers of hyperpolarization-activated current with isoform selectivity in recombinant cells and native tissue. Br. J. Pharmacol. 166, 602-616. doi: 10.1111/j.1476-5381.2011.01782.x

Denis, C., Saulière, A., Galandrin, S., Sénard, J. M., and Galés, C. (2012). Probing heterotrimeric $\mathrm{G}$ protein activation: applications to biased ligands. Curr. Pharm. Des. 18, 128-144. doi: 10.2174/138161212799040466

de Rooij, J., Zwartkruis, F. J., Verheijen, M. H., Cool, R. H., Nijman, S. M., Wittinghofer, A., et al. (1998). Epac is a Rap1 guanine-nucleotideexchange factor directly activated by cyclic AMP. Nature 396, 474-477. doi: $10.1038 / 24884$

Dessauer, C. W., Scully, T. T., and Gilman, A. G. (1997). Interactions of forskolin and ATP with the cytosolic domains of mammalian adenylyl cyclase. J. Biol. Chem. 272, 22272-22277. doi: 10.1074/jbc.272.35.22272

Dessauer, C. W., Tesmer, J. J., Sprang, S. R., and Gilman, A. G. (1999). The interactions of adenylate cyclases with P-site inhibitors. Trends Pharmacol. Sci. 20, 205-210. doi: 10.1016/S0165-6147(99)01310-3

Ding, B., Abe, J., Wei, H., Huang, Q., Walsh, R. A., Molina, C. A., et al. (2005a). Functional role of phosphodiesterase 3 in cardiomyocyte apoptosis: implication in heart failure. Circulation 111, 2469-2476. doi: 10.1161/01.CIR.0000165128.39715.87

Ding, B., Abe, J., Wei, H., Xu, H., Che, W., Aizawa, T., et al. (2005b). A positive feedback loop of phosphodiesterase 3 (PDE3) and inducible cAMP early repressor (ICER) leads to cardiomyocyte apoptosis. Proc. Natl. Acad. Sci. U.S.A. 102, 14771-147714776. doi: 10.1073/pnas.0506489102

Dodge, K. L., Khouangsathiene, S., Kapiloff, M. S., Mouton, R., Hill, E. V., Houslay, M. D., et al. (2001). mAKAP assembles a protein kinase A/PDE4 phosphodiesterase cAMP signaling module. EMBO J. 20, 1921-1930. doi: 10.1093/emboj/20.8.1921

Dunkern, T. R., and Hatzelmann, A. (2007). Characterization of inhibitors of phosphodiesterase 1 C on a human cellular system. FEBS J. 274, 4812-4824. doi: 10.1111/j.1742-4658.2007.06001.x

Ebina, T., Kawabe, J., Katada, T., Ohno, S., Homcy, C. J., and Ishikawa, Y. (1997). Conformation-dependent activation of type II adenylyl cyclase by protein kinase C. J. Cell. Biochem. 64, 492-498.

Edwards, H. V., Christian, F., and Baillie, G. S. (2012). cAMP: novel concepts in compartmentalised signalling. Semin. Cell Dev. Biol. 23, 181-190. doi: 10.1016/j.semcdb.2011.09.005

Efendiev, R., and Dessauer, C. W. (2011). A kinase-anchoring proteins and adenylyl cyclase in cardiovascular physiology and pathology. J. Cardiovasc. Pharmacol. 58, 339-344. doi: 10.1097/FJC.0b013e31821bc3f0

Efetova, M., Petereit, L., Rosiewicz, K., Overend, G., Haußig, F., Hovemann, B. T., et al. (2013). Separate roles of PKA and EPAC in renal function unraveled by the optogenetic control of cAMP levels in vivo. J. Cell Sci. 126, 778-788. doi: $10.1242 /$ jcs. 114140

Engelhardt, S., Hein, L., Wiesmann, F., and Lohse, M. J. (1999). Progressive hypertrophy and heart failure in betal-adrenergic receptor transgenic mice. Proc. Natl. Acad. Sci. U.S.A. 96, 7059-7064. doi: 10.1073/pnas.96.12.7059
Engh, R. A., Girod, A., Kinzel, V., Huber, R., and Bossemeyer, D. (1996). Crystal structures of catalytic subunit of cAMP-dependent protein kinase in complex with isoquinolinesulfonyl protein kinase inhibitors $\mathrm{H} 7, \mathrm{H} 8$, and H89. Structural implications for selectivity. J. Biol. Chem. 271, 26157-26164. doi: $10.1074 / \mathrm{jbc} .271 .42 .26157$

Enserink, J. M., Christensen, A. E., de Rooij, J., van Triest, M., Schwede, F., Genieser, H. G., et al. (2002). A novel Epac-specific cAMP analogue demonstrates independent regulation of Rap1 and ERK. Nat. Cell Biol. 4, 901-906. doi: 10.1038/ncb874

Erdorf, M., Mou, T. C., and Seifert, R. (2011). Impact of divalent metal ions on regulation of adenylyl cyclase isoforms by forskolin analogs. Biochem. Pharmacol. 82, 1673-1681. doi: 10.1016/j.bcp.2011.07.099

Eschenhagen, T., Mende, U., Nose, M., Schmitz, W., Scholz, H., Haverich, A., et al. (1992a). Increased messenger RNA level of the inhibitory $G$ protein alpha subunit Gi alpha-2 in human end-stage heart failure. Circ. Res. 70, 688-696. doi: 10.1161/01.RES.70.4.688

Eschenhagen, T., Mende, U., Nose, M., Schmitz, W., Scholz, H., Schulte am Esch, J., Sempell, R., et al. (1992b). Regulation and possible functional implications of G-protein mRNA expression in nonfailing and failing ventricular myocardium. Basic Res. Cardiol. 87(Suppl. 1), 51-64. doi: 10.1007/978-3-642-72474-9_4

Esposito, G., Perrino, C., Ozaki, T., Takaoka, H., Defer, N., Petretta, M. P., et al. (2008). Increased myocardial contractility and enhanced exercise function in transgenic mice overexpressing either adenylyl cyclase 5 or 8. Basic Res. Cardiol. 103, 22-30. doi: 10.1007/s00395-007-0688-6

Fan, F., Binkowski, B. F., Butler, B. L., Stecha, P. F., Lewis, M. K., and Wood, K. V. (2008). Novel genetically encoded biosensors using firefly luciferase. ACS Chem. Biol. 3, 346-351. doi: 10.1021/cb8000414

Filip, Z. A., Vanhauwe, J., Mathew, A., Eason, P. D., Ly, J. T., Leginus, J., et al. (2004). A Multi-Array ${ }^{\mathrm{TM}}$ Technology Based Assay for cAMP. Rockville, MD: Meso Scale Discovery Application note.

Fischmeister, R., Castro, L., Abi-Gerges, A., Rochais, F., and Vandecasteele, G. (2005). Species- and tissue-dependent effects of NO and cyclic GMP on cardiac ion channels. Comparative biochemistry and physiology. Part A Mol. Integr. Physiol. 142, 136-143. doi: 10.1016/j.cbpb.2005.04.012

Forster, T. (1946). Energiewanderung und Fluoreszenz. Naturwissenschaften 33, 166-175. doi: 10.1007/BF00585226

Fraser, I. D., Tavalin, S. J., Lester, L. B., Langeberg, L. K., Westphal, A. M., Dean, R. A., et al. (1998). A novel lipid-anchored A-kinase Anchoring Protein facilitates cAMP-responsive membrane events. EMBO J. 17, 2261-2272. doi: 10.1093/emboj/17.8.2261

Fredriksson, R., and Schiöth, H. B. (2005). The repertoire of G-protein-coupled receptors in fully sequenced genomes. Mol. Pharmacol. 67, 1414-1425. doi: 10.1124/mol.104.009001

Freissmuth, M., Boehm, S., Beindl, W., Nickel, P., Ijzerman, A. P., Hohenegger, M., et al. (1996). Suramin analogues as subtype-selective G protein inhibitors. Mol. Pharmacol. 49, 602-611.

Froese, A., Breher, S. S., Waldeyer, C., Schindler, R. F., Nikolaev, V. O., Rinné, S., et al. (2012). Popeye domain containing proteins are essential for stressmediated modulation of cardiac pacemaking in mice. J. Clin. Invest. 122, 1119-1130. doi: 10.1172/JCI59410

Gao, M. H., Lai, N. C., Roth, D. M., Zhou, J., Zhu, J., Anzai, T., et al. (1999). Adenylylcyclase increases responsiveness to catecholamine stimulation in transgenic mice. Circulation 99, 1618-1622. doi: 10.1161/01.CIR.99.12.1618

Gao, M. H., Tang, T., Guo, T., Miyanohara, A., Yajima, T., Pestonjamasp, K., et al. (2008). Adenylyl cyclase type VI increases Akt activity and phospholamban phosphorylation in cardiac myocytes. J. Biol. Chem. 283, 33527-33535. doi: 10.1074/jbc.M805825200

Gasser, C., Taiber, S., Yeh, C. M., Wittig, C. H., Hegemann, P., Ryu, S., et al. (2014). Engineering of a red-light-activated human cAMP/cGMPspecific phosphodiesterase. Proc. Natl. Acad. Sci. U.S.A. 111, 8803-8808. doi: $10.1073 /$ pnas. 1321600111

Gille, A., and Seifert, R. (2003). MANT-substituted guanine nucleotides: a novel class of potent adenylyl cyclase inhibitors. Life Sci. 74, 271-279. doi: 10.1016/j.lfs.2003.09.014

Gilman, A. G. (1987). G proteins: transducers of receptor-generated signals. Annu. Rev. Biochem. 56, 615-649. doi: 10.1146/annurev.bi.56.070187.003151

Glass, D. B., Feller, M. J., Levin, L. R., and Walsh, D. A. (1992). Structural basis for the low affinities of yeast cAMP-dependent and mammalian cGMP-dependent 
protein kinases for protein kinase inhibitor peptides. Biochemistry 31, 1728-1734. doi: 10.1021/bi00121a021

Golla, R., and Seethala, R. (2002). A homogeneous enzyme fragment complementation cyclic AMP screen for GPCR agonists. J. Biomol. Screen. 7, 515-525. doi: 10.1177/1087057102238625

Goodwin, L. R., Francom, D., Dieken, F. P., Taylor, J. D., Warenycia, M. W., Reiffenstein, R. J., et al. (1989). Determination of sulfide in brain tissue by gas dialysis/ion chromatography: postmortem studies and two case reports. J. Anal. Toxicol. 13, 105-109. doi: 10.1093/jat/13.2.105

Guellich, A., Gao, S., Hong, C., Yan, L., Wagner, T. E., Dhar, S. K., et al. (2010). Effects of cardiac overexpression of type 6 adenylyl cyclase affects on the response to chronic pressure overload. American journal of physiology. Heart Circul. Physiol. 299, H707-H712. doi: 10.1152/ajpheart.00148.2010

Guellich, A., Mehel, H., and Fischmeister, R. (2014). Cyclic AMP synthesis and hydrolysis in the normal and failing heart. Pflugers Arch. 466, 1163-1175. doi: 10.1007/s00424-014-1515-1

Guillou, J. L., Nakata, H., and Cooper, D. M. (1999). Inhibition by calcium of mammalian adenylyl cyclases. J. Biol. Chem. 274, 35539-35545. doi: $10.1074 /$ jbc. 274.50 .35539

Hagen, T. J., Mo, X., Burgin, A. B., Fox, D. I. I. I., Zhang, Z., and Gurney, M. E. (2014). Discovery of triazines as selective PDE4B versus PDE4D inhibitors. Bioorg. Med. Chem. Lett. 24, 4031-4034. doi: 10.1016/j.bmcl.2014.06.002

Hakak, Y., Shrestha, D., Goegel, M. C., Behan, D. P., and Chalmers, D. T. (2003). Global analysis of G-protein-coupled receptor signaling in human tissues. FEBS Lett. 550, 11-17. doi: 10.1016/S0014-5793(03)00762-2

Halls, M. L., and Cooper, D. M. (2011). Regulation by Ca2+-signaling pathways of adenylyl cyclases. Cold Spring Harb. Perspect. Biol. 3:a004143. doi: 10.1101/cshperspect.a004143

Han, S., and Meier, K. E. (2009). Integrated modulation of phorbol esterinduced Raf activation in EL4 lymphoma cells. Cell. Signal. 21, 793-800. doi: 10.1016/j.cellsig.2009.01.025

Hartzell, H. C., and Fischmeister, R. (1986). Opposite effects of cyclic GMP and cyclic AMP on Ca2+ current in single heart cells. Nature 323, 273-275. doi: $10.1038 / 323273 \mathrm{a} 0$

Hatzelmann, A., Morcillo, E. J., Lungarella, G., Adnot, S., Sanjar, S., Beume, R., et al. (2010). The preclinical pharmacology of roflumilast-a selective, oral phosphodiesterase 4 inhibitor in development for chronic obstructive pulmonary disease. Pulm. Pharmacol. Ther. 23, 235-256. doi: 10.1016/j.pupt.2010.03.011

Haunsø, A., Simpson, J., and Antoni, F. A. (2003). Small ligands modulating the activity of mammalian adenylyl cyclases: a novel mode of inhibition by calmidazolium. Mol. Pharmacol. 63, 624-631. doi: 10.1124/mol.63.3.624

Hébert, T. E., Galés, C., and Rebois, R. V. (2006). Detecting and imaging proteinprotein interactions during $\mathrm{G}$ protein-mediated signal transduction in vivo and in situ by using fluorescence-based techniques. Cell Biochem. Biophys. 45, 85-109. doi: 10.1385/CBB:45:1:85

Hess, S. M., Chasin, M., Free, C. A., and Harris, D. N. (1975). Modulators of cyclic AMP systems. Psychopharmacol. Bull. 11, 57-58.

Hidaka, H., Hayashi, H., Kohri, H., Kimura, Y., Hosokawa, T., Igawa, T., et al. (1979). Selective inhibitor of platelet cyclic adenosine monophosphate phosphodiesterase, cilostamide, inhibits platelet aggregation. J. Pharmacol. Exp. Ther. 211, 26-30.

Hofmann, F., Beavo, J. A., Bechtel, P. J., and Krebs, E. G. (1975). Comparison of adenosine $3^{\prime}: 5^{\prime}$-monophosphate-dependent protein kinases from rabbit skeletal and bovine heart muscle. J. Biol. Chem. 250, 7795-7801.

Hohenegger, M., Waldhoer, M., Beindl, W., Böing, B., Kreimeyer, A., Nickel, P., et al. (1998). Gsalpha-selective G protein antagonists. Proc. Natl. Acad. Sci. U.S.A. 95, 346-351. doi: 10.1073/pnas.95.1.346

Horton, J. K., and Baxendale, P. M. (1995). Mass measurements of cyclic AMP formation by radioimmunoassay, enzyme immunoassay, and scintillation proximity assay. Methods Mol. Biol. 41, 91-105. doi: 10.1385/0-89603-298-1:91

Houslay, M. D. (2001). PDE4 cAMP-specific phosphodiesterases. Prog. Nucleic Acid Res. Mol. Biol. 69, 249-315. doi: 10.1016/S0079-6603(01)69049-4

Hsia, J. A., Moss, J., Hewlett, E. L., and Vaughan, M. (1984). Requirement for both choleragen and pertussis toxin to obtain maximal activation of adenylate cyclase in cultured cells. Biochem. Biophys. Res. Commun. 119, 1068-1074. doi: 10.1016/0006-291X(84)90883-0
Hu, B., Nakata, H., Gu, C., De Beer, T., and Cooper, D. M. (2002). A critical interplay between $\mathrm{Ca} 2+$ inhibition and activation by $\mathrm{Mg} 2+$ of $\mathrm{AC} 5$ revealed by mutants and chimeric constructs. J. Biol. Chem. 277, 33139-33147. doi: 10.1074/jbc.M112373200

Huang, W., Zhang, Y., and Sportsman, J. R. (2002). A fluorescence polarization assay for cyclic nucleotide phosphodiesterases. J. Biomol. Screen. 7, 215-222. doi: $10.1177 / 108705710200700305$

Huang, X. D., and Wong, T. M. (1989). Cholera toxin enhances ischemia-induced arrhythmias in the isolated rat heart-involvement of a guanine nucleotide binding protein (Gs). Life Sci. 45, 679-683. doi: 10.1016/0024-3205(89)90085-4

Hudson, T. Y., Corbett, J. A., Howlett, A. C., and Klein, C. (2001). Nitric oxide regulates adenylyl cyclase activity in rat striatal membranes. J. Neurochem. 77, 1279-1284. doi: 10.1046/j.1471-4159.2001.00331.x

Ito, K., Liu, H., Komiyama, M., Hayashi, T., and Xu, Y. (2013). Direct light-up of cAMP derivatives in living cells by click reactions. Molecules 18, 12909-12915. doi: 10.3390/molecules181012909

Iwamoto, T., Okumura, S., Iwatsubo, K., Kawabe, J., Ohtsu, K., Sakai, I., et al. (2003). Motor dysfunction in type 5 adenylyl cyclase-null mice. J. Biol. Chem. 278, 16936-16940. doi: 10.1074/jbc.C300075200

Iwaya, S., Oikawa, M., Chen, Y., and Takeishi, Y. (2014). Phosphodiesterase 3A1 protects the heart against angiotensin II-induced cardiac remodeling through regulation of transforming growth factor-beta expression. Int. Heart J. 55, 165-168. doi: 10.1536/ihj.13-268

Jin, S. L., Lan, L., Zoudilova, M., and Conti, M. (2005). Specific role of phosphodiesterase 4B in lipopolysaccharide-induced signaling in mouse macrophages. J. Immunol. 175, 1523-1531. doi: 10.4049/jimmunol.175.3.1523

Jurevicius, J., and Fischmeister, R. (1996a). Acetylcholine inhibits Ca2+ current by acting exclusively at a site proximal to adenylyl cyclase in frog cardiac myocytes. J. Physiol. 491(Pt 3), 669-675. doi: 10.1113/jphysiol.1996.sp021248

Jurevicius, J., and Fischmeister, R. (1996b). cAMP compartmentation is responsible for a local activation of cardiac $\mathrm{Ca} 2+$ channels by beta-adrenergic agonists. Proc. Natl. Acad. Sci. U.S.A. 93, 295-299. doi: 10.1073/pnas. 93.1.295

Kadoshima-Yamaoka, K., Murakawa, M., Goto, M., Tanaka, Y., Inoue, H., Murafuji, H., et al. (2009). ASB16165, a novel inhibitor for phosphodiesterase 7A (PDE7A), suppresses IL-12-induced IFN-gamma production by mouse activated $\mathrm{T}$ lymphocytes. Immunol. Lett. 122, 193-197. doi: 10.1016/j.imlet.2009.01.004

Kapiloff, M. S., Piggott, L. A., Sadana, R., Li, J., Heredia, L. A., Henson, E., et al. (2009). An adenylyl cyclase-mAKAPbeta signaling complex regulates cAMP levels in cardiac myocytes. J. Biol. Chem. 284, 23540-23546. doi: 10.1074/jbc.M109.030072

Kapiloff, M. S., Rigatti, M., and Dodge-Kafka, K. L. (2014). Architectural and functional roles of A kinase-anchoring proteins in cAMP microdomains. J. Gen. Physiol. 143, 9-15. doi: 10.1085/jgp.201311020

Kase, H., Iwahashi, K., Nakanishi, S., Matsuda, Y., Yamada, K., Takahashi, M., et al. (1987). K-252 compounds, novel and potent inhibitors of protein kinase C and cyclic nucleotide-dependent protein kinases. Biochem. Biophys. Res. Commun. 142, 436-440. doi: 10.1016/0006-291X(87)90293-2

Katugampola, S., and Davenport, A. (2003). Emerging roles for orphan G-proteincoupled receptors in the cardiovascular system. Trends Pharmacol. Sci. 24, 30-35. doi: 10.1016/S0165-6147(02)00007-X

Kawasaki, H., Springett, G. M., Mochizuki, N., Toki, S., Nakaya, M., Matsuda, M., et al. (1998). A family of cAMP-binding proteins that directly activate Rap1. Science 282, 2275-2279. doi: 10.1126/science.282.5397.2275

Kazanietz, M. G., Lewin, N. E., Bruns, J. D., and Blumberg, P. M. (1995). Characterization of the cysteine-rich region of the Caenorhabditis elegans protein Unc-13 as a high affinity phorbol ester receptor. Analysis of ligandbinding interactions, lipid cofactor requirements, and inhibitor sensitivity. J. Biol. Chem. 270, 10777-10783. doi: 10.1074/jbc.270.18.10777

Kimura, H. (2000). Hydrogen sulfide induces cyclic AMP and modulates the NMDA receptor. Biochem. Biophys. Res. Commun. 267, 129-133. doi: 10.1006/bbrc.1999.1915

Kiuchi, K., Shannon, R. P., Komamura, K., Cohen, D. J., Bianchi, C., Homcy, C. J., et al. (1993). Myocardial beta-adrenergic receptor function during the development of pacing-induced heart failure. J. Clin. Invest. 91, 907-914. doi: 10.1172/JCI116312 
Kiyokawa, E., Hara, S., Nakamura, T., and Matsuda, M. (2006). Fluorescence (Forster) resonance energy transfer imaging of oncogene activity in living cells. Cancer Sci. 97, 8-15. doi: 10.1111/j.1349-7006.2006.00141.x

Klarenbeek, J., and Jalink, K. (2014). Detecting cAMP with an EPAC-based FRET sensor in single living cells. Methods Mol. Biol. 1071, 49-58. doi: 10.1007/9781-62703-622-1_4

Kruh, G. D., and Belinsky, M. G. (2003). The MRP family of drug efflux pumps. Oncogene 22, 7537-7552. doi: 10.1038/sj.onc.1206953

Kumar, S., Kostin, S., Flacke, J. P., Reusch, H. P., and Ladilov, Y. (2009). Soluble adenylyl cyclase controls mitochondria-dependent apoptosis in coronary endothelial cells. J. Biol. Chem. 284, 14760-14768. doi: 10.1074/jbc.M900925200

Lai, L., Yan, L., Gao, S., Hu, C. L., Ge, H., Davidow, A., et al. (2013). Type 5 adenylyl cyclase increases oxidative stress by transcriptional regulation of manganese superoxide dismutase via the SIRT1/FoxO3a pathway. Circulation 127, 1692-1701. doi: 10.1161/CIRCULATIONAHA.112.001212

Lander, E. S., Linton, L. M., Birren, B., Nusbaum, C., Zody, M. C., Baldwin, J., et al. (2001). Initial sequencing and analysis of the human genome. Nature 409, 860-921. doi: 10.1038/35057062

Laurenza, A., Sutkowski, E. M., and Seamon, K. B. (1989). Forskolin: a specific stimulator of adenylyl cyclase or a diterpene with multiple sites of action? Trends Pharmacol. Sci. 10, 442-447. doi: 10.1016/S0165-6147(89)80008-2

Lehmann, D. M., Seneviratne, A. M., and Smrcka, A. V. (2008). Small molecule disruption of $\mathrm{G}$ protein beta gamma subunit signaling inhibits neutrophil chemotaxis and inflammation. Mol. Pharmacol. 73, 410-418. doi: 10.1124/mol.107.041780

Lehnart, S. E., Wehrens, X. H., Reiken, S., Warrier, S., Belevych, A. E., Harvey, R. D., et al. (2005). Phosphodiesterase 4D deficiency in the ryanodinereceptor complex promotes heart failure and arrhythmias. Cell 123, 25-35. doi: 10.1016/j.cell.2005.07.030

Leroy, J., Richter, W., Mika, D., Castro, L. R., Abi-Gerges, A., Xie, M., et al. (2011). Phosphodiesterase $4 \mathrm{~B}$ in the cardiac L-type $\mathrm{Ca}(2)(+)$ channel complex regulates $\mathrm{Ca}(2)(+)$ current and protects against ventricular arrhythmias in mice. J. Clin. Invest. 121, 2651-2661. doi: 10.1172/JCI44747

Lezoualc'h, F., Jockers, R., and Berque-Bestel, I. (2009). Multivalent-based drug design applied to serotonin 5-HT(4) receptor oligomers. Curr. Pharm. Des. 15, 719-729. doi: 10.2174/138161209787315602

Lim, J. J., Liu, Y. H., Khin, E. S., and Bian, J. S. (2008). Vasoconstrictive effect of hydrogen sulfide involves downregulation of cAMP in vascular smooth muscle cells. American journal of physiology. Cell Physiol. 295, C1261-C1270. doi: 10.1152/ajpcell.00195.2008

Lipskaia, L., Defer, N., Esposito, G., Hajar, I., Garel, M. C., Rockman, H. A., et al. (2000). Enhanced cardiac function in transgenic mice expressing a $\mathrm{Ca}^{(2+)}$-stimulated adenylyl cyclase. Circ. Res. 86, 795-801. doi: 10.1161/01.RES.86.7.795

Lohse, M. J., Engelhardt, S., and Eschenhagen, T. (2003). What is the role of beta-adrenergic signaling in heart failure? Circ. Res. 93, 896-906. doi: 10.1161/01.RES.0000102042.83024.CA

MacKenzie, S. J., Baillie, G. S., McPhee, I., MacKenzie, C., Seamons, R., McSorley, T., et al. (2002). Long PDE4 cAMP specific phosphodiesterases are activated by protein kinase A-mediated phosphorylation of a single serine residue in Upstream Conserved Region 1 (UCR1). Br. J. Pharmacol. 136, 421-433. doi: 10.1038/sj.bjp.0704743

Mattick, P., Parrington, J., Odia, E., Simpson, A., Collins, T., and Terrar, D. (2007). $\mathrm{Ca} 2+$-stimulated adenylyl cyclase isoform $\mathrm{AC} 1$ is preferentially expressed in guinea-pig sino-atrial node cells and modulates the I(f) pacemaker current. J. Physiol. (Lond). 582, 1195-1203. doi: 10.1113/jphysiol.2007.133439

McMurray, J. J., and Pfeffer, M. A. (2005). Heart failure. Lancet 365, 1877-1889. doi: 10.1016/S0140-6736(05)66621-4

Melchiorre, M., Del Lungo, M., Guandalini, L., Martini, E., Dei, S., Manetti, D., et al. (2010). Design, synthesis, and preliminary biological evaluation of new isoform-selective f-current blockers. J. Med. Chem. 53, 6773-6777. doi: $10.1021 / \mathrm{jm} 1006758$

Melsom, C. B., Hussain, R. I., Ørstavik, Ø., Aronsen, J. M., Sjaastad, I., Skomedal, T., et al. (2014). Non-classical regulation of beta1- and beta 2-adrenoceptormediated inotropic responses in rat heart ventricle by the G protein Gi. Naunyn Schmiedebergs Arch. Pharmacol. 387, 1177-1186. doi: 10.1007/s00210-0141036-7
Métrich, M., Lucas, A., Gastineau, M., Samuel, J. L., Heymes, C., Morel, E., et al. (2008). Epac mediates beta-adrenergic receptor-induced cardiomyocyte hypertrophy. Circ. Res. 102, 959-965. doi: 10.1161/CIRCRESAHA.107. 164947

Michel, M. C., Maisel, A. S., and Brodde, O. E. (1990). Mitigation of beta 1- and/or beta 2-adrenoceptor function in human heart failure. British journal of clinical pharmacology 30(Suppl. 1), 37S-42S. doi: 10.1111/j.1365-2125.1990.tb05466.x

Miller, C. L., Cai, Y., Oikawa, M., Thomas, T., Dostmann, W. R., Zaccolo, M., et al. (2011). Cyclic nucleotide phosphodiesterase 1A: a key regulator of cardiac fibroblast activation and extracellular matrix remodeling in the heart. Basic Res. Cardiol. 106, 1023-1039. doi: 10.1007/s00395-011-0228-2

Molenaar, P., Christ, T., Hussain, R. I., Engel, A., Berk, E., Gillette, K. T., et al. (2013). PDE3, but not PDE4, reduces beta(1) - and beta(2)adrenoceptor-mediated inotropic and lusitropic effects in failing ventricle from metoprolol-treated patients. Br. J. Pharmacol. 169, 528-538. doi: 10.1111/bph. 12167

Molina-Muñoz, T., Romero-Avila, M. T., and García-Sáinz, J. A. (2006). Insulinlike growth factor-I induces alpha(1B)-adrenergic receptor phosphorylation through $\mathrm{G}$ beta gamma and epidermal growth factor receptor transactivation. Mol. Endocrinol. 20, 2773-2783. doi: 10.1210/me.2006-0090

Moore-Morris, T., Varrault, A., Mangoni, M. E., Le Digarcher, A., Negre, V., Dantec, C., et al. (2009). Identification of potential pharmacological targets by analysis of the comprehensive $G$ protein-coupled receptor repertoire in the four cardiac chambers. Mol. Pharmacol. 75, 1108-1116. doi: 10.1124/mol.108.054155

Mou, T. C., Masada, N., Cooper, D. M., and Sprang, S. R. (2009). Structural basis for inhibition of mammalian adenylyl cyclase by calcium. Biochemistry 48, 3387-3397. doi: 10.1021/bi802122k

Mukherjee, R., and Spinale, F. G. (1998). L-type calcium channel abundance and function with cardiac hypertrophy and failure: a review. J. Mol. Cell. Cardiol. 30, 1899-1916. doi: 10.1006/jmcc.1998.0755

Murray, A. J. (2008). Pharmacological PKA inhibition: all may not be what it seems. Sci. Signal. 1:re4. doi: 10.1126/scisignal.122re4

Nair, B. G., and Patel, T. B. (1993). Regulation of cardiac adenylyl cyclase by epidermal growth factor (EGF). Role of EGF receptor protein tyrosine kinase activity. Biochem. Pharmacol. 46, 1239-1245. doi: 10.1016/00062952(93)90473-A

Nichols, C. B., Rossow, C. F., Navedo, M. F., Westenbroek, R. E., Catterall, W. A., Santana, L. F., et al. (2010). Sympathetic stimulation of adult cardiomyocytes requires association of AKAP5 with a subpopulation of L-type calcium channels. Circ. Res. 107, 747-756. doi: 10.1161/CIRCRESAHA.109.216127

Niimura, M., Miki, T., Shibasaki, T., Fujimoto, W., Iwanaga, T., and Seino, S. (2009). Critical role of the N-terminal cyclic AMP-binding domain of Epac2 in its subcellular localization and function. J. Cell. Physiol. 219, 652-658. doi: $10.1002 /$ jcp. 21709

Nikolaev, V. O., Moshkov, A., Lyon, A. R., Miragoli, M., Novak, P., Paur, H., et al. (2010). Beta2-adrenergic receptor redistribution in heart failure changes cAMP compartmentation. Science 327, 1653-1657. doi: 10.1126/science.1185988

Okumura, S., Kawabe, J., Yatani, A., Takagi, G., Lee, M. C., Hong, C., et al. (2003a). Type 5 adenylyl cyclase disruption alters not only sympathetic but also parasympathetic and calcium-mediated cardiac regulation. Circ. Res. 93, 364-371. doi: 10.1161/01.RES.0000086986.35568.63

Okumura, S., Takagi, G., Kawabe, J., Yang, G., Lee, M. C., Hong, C., et al. (2003b). Disruption of type 5 adenylyl cyclase gene preserves cardiac function against pressure overload. Proc. Natl. Acad. Sci. U.S.A. 100, 9986-9990. doi: $10.1073 /$ pnas. 1733772100

Omori, K., and Kotera, J. (2007). Overview of PDEs and their regulation. Circ. Res. 100, 309-327. doi: 10.1161/01.RES.0000256354.95791.f1

Onda, T., Hashimoto, Y., Nagai, M., Kuramochi, H., Saito, S., Yamazaki, H., et al. (2001). Type-specific regulation of adenylyl cyclase. Selective pharmacological stimulation and inhibition of adenylyl cyclase isoforms. J. Biol. Chem. 276, 47785-47793. doi: 10.1074/jbc.M107233200

Orth, J. H., Fester, I., Preuss, I., Agnoletto, L., Wilson, B. A., and Aktories, K. (2008). Activation of Galpha (i) and subsequent uncoupling of receptor-Galpha(i) signaling by Pasteurella multocida toxin. J. Biol. Chem. 283, 23288-23294. doi: 10.1074/jbc.M803435200

Orth, J. H., Lang, S., Taniguchi, M., and Aktories, K. (2005). Pasteurella multocida toxin-induced activation of RhoA is mediated via two families of G\{alpha\} 
proteins, G\{alpha\}q and G\{alpha\}12/13. J. Biol. Chem. 280, 36701-36707. doi: 10.1074/jbc.M507203200

Ostrom, R. S., Gregorian, C., Drenan, R. M., Xiang, Y., Regan, J. W., and Insel, P. A. (2001). Receptor number and caveolar co-localization determine receptor coupling efficiency to adenylyl cyclase. J. Biol. Chem. 276, 42063-42069. doi: 10.1074/jbc.M105348200

Pape, H. C. (1996). Queer current and pacemaker: the hyperpolarizationactivated cation current in neurons. Annu. Rev. Physiol. 58, 299-327. doi: 10.1146/annurev.ph.58.030196.001503

Patrucco, E., Albergine, M. S., Santana, L. F., and Beavo, J. A. (2010). Phosphodiesterase $8 \mathrm{~A}$ (PDE8A) regulates excitation-contraction coupling in ventricular myocytes. J. Mol. Cell. Cardiol. 49, 330-333. doi: 10.1016/j.yjmcc.2010.03.016

Pereira, L., Métrich, M., Fernández-Velasco, M., Lucas, A., Leroy, J., Perrier, R., et al. (2007). The cAMP binding protein Epac modulates Ca2+ sparks by a $\mathrm{Ca} 2+/$ calmodulin kinase signalling pathway in rat cardiac myocytes. J. Physiol. (Lond). 583, 685-694. doi: 10.1113/jphysiol.2007.133066

Perera, R. K., and Nikolaev, V. O. (2013). Compartmentation of cAMP signalling in cardiomyocytes in health and disease. Acta Physiol. 207, 650-662. doi: 10.1111/apha.12077

Pertseva, M. N., Shpakov, A. O., Plesneva, S. A., and Kuznetsova, L. A. (2003). A novel view on the mechanisms of action of insulin and other insulin superfamily peptides: involvement of adenylyl cyclase signaling system. Comparative biochemistry and physiology. Part B Biochem. Mol. Biol. 134, 11-36. doi: 10.1016/S1096-4959(02)00160-4

Phan, H. M., Gao, M. H., Lai, N. C., Tang, T., and Hammond, H. K. (2007). New signaling pathways associated with increased cardiac adenylyl cyclase 6 expression: implications for possible congestive heart failure therapy. Trends Cardiovasc. Med. 17, 215-221. doi: 10.1016/j.tcm.2007.07.001

Piggott, L. A., Bauman, A. L., Scott, J. D., and Dessauer, C. W. (2008). The A-kinase anchoring protein Yotiao binds and regulates adenylyl cyclase in brain. Proc. Natl. Acad. Sci. U.S.A. 105, 13835-13840. doi: 10.1073/pnas.0712100105

Piñeyro, G., Azzi, M., deLéan, A., Schiller, P. W., and Bouvier, M. (2005). Reciprocal regulation of agonist and inverse agonist signaling efficacy upon short-term treatment of the human delta-opioid receptor with an inverse agonist. Mol. Pharmacol. 67, 336-348. doi: 10.1124/mol.104.004549

Podda, M. V., and Grassi, C. (2014). New perspectives in cyclic nucleotidemediated functions in the CNS: the emerging role of cyclic nucleotide-gated (CNG) channels. Pflugers Arch. 466, 1241-1257. doi: 10.1007/s00424-0131373-2

Podzuweit, T., Müller, A., and Opie, L. H. (1993). Anti-arrhythmic effects of selective inhibition of myocardial phosphodiesterase II. Lancet 341, 760. doi: 10.1016/0140-6736(93)90534-N

Poppe, H., Rybalkin, S. D., Rehmann, H., Hinds, T. R., Tang, X. B., Christensen, A. E., et al. (2008). Cyclic nucleotide analogs as probes of signaling pathways. Nat. Methods 5, 277-278. doi: 10.1038/nmeth0408-277

Prévost, G. P., Lonchampt, M. O., Holbeck, S., Attoub, S., Zaharevitz, D., Alley, M., et al. (2006). Anticancer activity of BIM-46174, a new inhibitor of the heterotrimeric Galpha/Gbetagamma protein complex. Cancer Res. 66, 9227-9234. doi: 10.1158/0008-5472.CAN-05-4205

Prystay, L., Gagné, A., Kasila, P., Yeh, L. A., and Banks, P. (2001). Homogeneous cell-based fluorescence polarization assay for the direct detection of cAMP. J. Biomol. Screen. 6, 75-82. doi: 10.1177/108705710100600203

Rabe, K. F. (2011). Update on roflumilast, a phosphodiesterase 4 inhibitor for the treatment of chronic obstructive pulmonary disease. Br. J. Pharmacol. 163, 53-67. doi: 10.1111/j.1476-5381.2011.01218.x

Regard, J. B., Sato, I. T., and Coughlin, S. R. (2008). Anatomical profiling of $\mathrm{G}$ protein-coupled receptor expression. Cell 135, 561-571. doi: 10.1016/j.cell.2008.08.040

Reid, G., Wielinga, P., Zelcer, N., van der Heijden, I., Kuil, A., de Haas, M., et al. (2003). The human multidrug resistance protein MRP4 functions as a prostaglandin efflux transporter and is inhibited by nonsteroidal antiinflammatory drugs. Proc. Natl. Acad. Sci. U.S.A. 100, 9244-9249. doi: 10.1073/pnas.1033060100

Rostovtsev, V. V., Green, L. G., Fokin, V. V., and Sharpless, K. B. (2002). A stepwise huisgen cycloaddition process: copper(I)-catalyzed regioselective "ligation" of azides and terminal alkynes. Angewandte Chemie 41, 2596-2599. doi: 10.1002/1521-3773(20020715)41:14\&lt;2596::AID-ANIE2596\&gt;3.0.CO;2-4
Rybalkin, S. D., Rybalkina, I., Beavo, J. A., and Bornfeldt, K. E. (2002). Cyclic nucleotide phosphodiesterase 1C promotes human arterial smooth muscle cell proliferation. Circ. Res. 90, 151-157. doi: 10.1161/hh0202. 104108

Rybin, V. O., Xu, X., Lisanti, M. P., and Steinberg, S. F. (2000). Differential targeting of beta -adrenergic receptor subtypes and adenylyl cyclase to cardiomyocyte caveolae. A mechanism to functionally regulate the cAMP signaling pathway. J. Biol. Chem. 275, 41447-41457. doi: 10.1074/jbc.M0069 51200

Sandberg, M., Butt, E., Nolte, C., Fischer, L., Halbrügge, M., Beltman, J., et al. (1991). Characterization of Sp-5,6-dichloro-1-beta-Dribofuranosylbenzimidazole- $\quad 3^{\prime}, 5^{\prime}$-monophosphorothioate (Sp-5,6-DClcBiMPS) as a potent and specific activator of cyclic-AMP-dependent protein kinase in cell extracts and intact cells. Biochem. J. 279(Pt 2), 521-527. doi: 10.1042/bj2790521

Sassi, Y., Abi-Gerges, A., Fauconnier, J., Mougenot, N., Reiken, S., Haghighi, K., et al. (2012). Regulation of cAMP homeostasis by the efflux protein MRP4 in cardiac myocytes. FASEB J. 26, 1009-1017. doi: 10.1096/fj.11-194027

Sassi, Y., Lipskaia, L., Vandecasteele, G., Nikolaev, V. O., Hatem, S. N., Cohen Aubart, F., et al. (2008). Multidrug resistance-associated protein 4 regulates cAMP-dependent signaling pathways and controls human and rat SMC proliferation. J. Clin. Invest. 118, 2747-2757. doi: 10.1172/JCI35067

Schaap, P., van Ments-Cohen, M., Soede, R. D., Brandt, R., Firtel, R. A., Dostmann, W., et al. (1993). Cell-permeable non-hydrolyzable cAMP derivatives as tools for analysis of signaling pathways controlling gene regulation in Dictyostelium. J. Biol. Chem. 268, 6323-6331.

Schindler, R. F., Poon, K. L., Simrick, S., and Brand, T. (2012). The Popeye domain containing genes: essential elements in heart rate control. Cardiovasc. Diagn. Ther. 2, 308-319. doi: 10.3978/j.issn.2223-3652.2012.12.01

Schmitz, A. L., Schrage, R., Gaffal, E., Charpentier, T. H., Wiest, J., Hiltensperger, G., et al. (2014). A cell-permeable inhibitor to trap Galphaq proteins in the empty pocket conformation. Chem. Biol. 21, 890-902. doi: 10.1016/j.chembiol.2014.06.003

Schwabe, U., Miyake, M., Ohga, Y., and Daly, J. W. (1976). 4-(3-Cyclopentyloxy4-methoxyphenyl)-2-pyrrolidone (ZK 62711): a potent inhibitor of adenosine cyclic 3',5'-monophosphate phosphodiesterases in homogenates and tissue slices from rat brain. Mol. Pharmacol. 12, 900-910.

Scicchitano, P., Carbonara, S., Ricci, G., Mandurino, C., Locorotondo, M., Bulzis, G., et al. (2012). HCN channels and heart rate. Molecules 17, 4225-4235. doi: $10.3390 /$ molecules 17044225

Seifert, R. (2014). Vidarabine is neither a potent nor a selective AC5 inhibitor. Biochem. Pharmacol. 87, 543-546. doi: 10.1016/j.bcp.2013.12.025

Seifert, R., Lushington, G. H., Mou, T. C., Gille, A., and Sprang, S. R. (2012). Inhibitors of membranous adenylyl cyclases. Trends Pharmacol. Sci. 33, 64-78. doi: 10.1016/j.tips.2011.10.006

Sellers, Z. M., Naren, A. P., Xiang, Y., and Best, P. M. (2012). MRP4 and CFTR in the regulation of cAMP and beta-adrenergic contraction in cardiac myocytes. Eur. J. Pharmacol. 68, 80-87. doi: 10.1016/j.ejphar.2012.02.018

Shaw, R. M., and Colecraft, H. M. (2013). L-type calcium channel targeting and local signalling in cardiac myocytes. Cardiovasc. Res. 98, 177-186. doi: $10.1093 / \mathrm{cvr} / \mathrm{cvt} 021$

Shimizu-Albergine, M., Tsai, L. C., Patrucco, E., and Beavo, J. A. (2012). cAMPspecific phosphodiesterases $8 \mathrm{~A}$ and $8 \mathrm{~B}$, essential regulators of Leydig cell steroidogenesis. Mol. Pharmacol. 81, 556-566. doi: 10.1124/mol.111.076125

Shui, B., Lee, J. C., Reining, S., Lee, F. K., and Kotlikoff, M. I. (2014). Optogenetic sensors and effectors: CHROMus-the Cornell Heart Lung Blood Institute Resource for Optogenetic Mouse Signaling. Front. Physiol. 5:428. doi: $10.3389 /$ fphys.2014.00428

Skalhegg, B. S., and Tasken, K. (2000). Specificity in the cAMP/PKA signaling pathway. Differential expression,regulation, and subcellular localization of subunits of PKA. Front. Biosci. 5, D678-D693.

Soderling, S. H., Bayuga, S. J., and Beavo, J. A. (1998). Cloning and characterization of a cAMP-specific cyclic nucleotide phosphodiesterase. Proc. Natl. Acad. Sci. U.S.A. 95, 8991-8996. doi: 10.1073/pnas.95.15.8991

Somekawa, S., Fukuhara, S., Nakaoka, Y., Fujita, H., Saito, Y., and Mochizuki, N. (2005). Enhanced functional gap junction neoformation by protein kinase A-dependent and Epac-dependent signals downstream of cAMP in cardiac myocytes. Circ. Res. 97, 655-662. doi: 10.1161/01.RES.0000183880.49270.f9 
Sprenger, J. U., and Nikolaev, V. O. (2013). Biophysical Techniques for Detection of cAMP and cGMP in Living Cells. Int. J. Mol. Sci. 14, 8025-8046. doi: 10.3390/ijms14048025

Sprenger, J. U., Perera, R. K., Steinbrecher, J. H., Lehnart, S. E., Maier, L. S., Hasenfuss, G., et al. (2015). In vivo model with targeted cAMP biosensor reveals changes in receptor-microdomain communication in cardiac disease. Nat. Commun. 6, 6965. doi: 10.1038/ncomms7965

Standaert, M. L., Galloway, L., Karnam, P., Bandyopadhyay, G., Moscat, J., and Farese, R. V. (1997). Protein kinase C-zeta as a downstream effector of phosphatidylinositol 3-kinase during insulin stimulation in rat adipocytes. Potential role in glucose transport. J. Biol. Chem. 272, 30075-30082. doi: 10.1074/jbc.272.48.30075

Stierl, M., Stumpf, P., Udwari, D., Gueta, R., Hagedorn, R., Losi, A., et al. (2011). Light modulation of cellular cAMP by a small bacterial photoactivated adenylyl cyclase, bPAC, of the soil bacterium Beggiatoa. J. Biol. Chem. 286, 1181-1188. doi: 10.1074/jbc.M110.185496

Sudo, T., Tachibana, K., Toga, K., Tochizawa, S., Inoue, Y., Kimura, Y., et al. (2000). Potent effects of novel anti-platelet aggregatory cilostamide analogues on recombinant cyclic nucleotide phosphodiesterase isozyme activity. Biochem. Pharmacol. 59, 347-356. doi: 10.1016/S0006-2952(99)00346-9

Sun, B., Li, H., Shakur, Y., Hensley, J., Hockman, S., Kambayashi, J., et al. (2007). Role of phosphodiesterase type $3 \mathrm{~A}$ and $3 \mathrm{~B}$ in regulating platelet and cardiac function using subtype-selective knockout mice. Cell. Signal. 19, 1765-1771. doi: 10.1016/j.cellsig.2007.03.012

Tang, C. M., and Insel, P. A. (2004). GPCR expression in the heart; "new" receptors in myocytes and fibroblasts. Trends Cardiovasc. Med. 14, 94-99. doi: $10.1016 /$ j.tcm.2003.12.007

Tang, T., Gao, M. H., Lai, N. C., Firth, A. L., Takahashi, T., Guo, T., et al. (2008). Adenylyl cyclase type 6 deletion decreases left ventricular function via impaired calcium handling. Circulation 117, 61-69. doi: 10.1161/CIRCULATIONAHA.107.730069

Tang, T., Lai, N. C., Hammond, H. K., Roth, D. M., Yang, Y., Guo, T., et al. (2010). Adenylyl cyclase 6 deletion reduces left ventricular hypertrophy, dilation, dysfunction, and fibrosis in pressure-overloaded female mice. J. Am. Coll. Cardiol. 55, 1476-1486. doi: 10.1016/j.jacc.2009.11.066

Tang, T., Lai, N. C., Roth, D. M., Drumm, J., Guo, T., Lee, K. W., et al. (2006). Adenylyl cyclase type $\mathrm{V}$ deletion increases basal left ventricular function and reduces left ventricular contractile responsiveness to beta-adrenergic stimulation. Basic Res. Cardiol. 101, 117-126. doi: 10.1007/s00395-005-0559-y

Tarpey, S. B., Sawmiller, D. R., Kelly, C., Thompson, W. J., and Townsley, M. I. (2003). Phosphodiesterase 3 activity is reduced in dog lung following pacinginduced heart failure. American journal of physiology. Lung Cell. Mol. Physiol. 284, L766-L773. doi: 10.1152/ajplung.00373.2002

Taskén, K. A., Collas, P., Kemmner, W. A., Witczak, O., Conti, M., and Tasken, K. (2001). Phosphodiesterase 4D and protein kinase a type II constitute a signaling unit in the centrosomal area. J. Biol. Chem. 276, 21999-22002. doi: 10.1074/jbc.C000911200

Tepe, N. M., Lorenz, J. N., Yatani, A., Dash, R., Kranias, E. G., Dorn, G. W., et al. (1999). Altering the receptor-effector ratio by transgenic overexpression of type $\mathrm{V}$ adenylyl cyclase: enhanced basal catalytic activity and function without increased cardiomyocyte beta-adrenergic signalling. Biochemistry 38, 16706-16713. doi: 10.1021/bi991619k

Tesmer, J. J., Sunahara, R. K., Gilman, A. G., and Sprang, S. R. (1997). Crystal structure of the catalytic domains of adenylyl cyclase in a complex with Gsalpha.GTPgammaS. Science 278, 1907-1916. doi: 10.1126/science.278.5345.1907

Tesmer, J. J., Sunahara, R. K., Johnson, R. A., Gosselin, G., Gilman, A. G., and Sprang, S. R. (1999). Two-metal-Ion catalysis in adenylyl cyclase. Science 285, 756-760. doi: 10.1126/science.285.5428.756

Tornøe, C. W., Christensen, C., and Meldal, M. (2002). Peptidotriazoles on solid phase: [1,2,3]-triazoles by regiospecific copper(i)-catalyzed 1,3-dipolar cycloadditions of terminal alkynes to azides. J. Org. Chem. 67, 3057-3064. doi: $10.1021 / \mathrm{jo} 011148 \mathrm{j}$

Trehan, A., Rotgers, E., Coffey, E. T., Huhtaniemi, I., and Rivero-Müller, A. (2014). CANDLES, an assay for monitoring GPCR induced cAMP generation in cell cultures. Cell Commun. Signal. 12:70. doi: 10.1186/s12964-014-0070-x

Tsalkova, T., Mei, F. C., Li, S., Chepurny, O. G., Leech, C. A., Liu, T., et al. (2012). Isoform-specific antagonists of exchange proteins directly activated by
cAMP. Proc. Natl. Acad. Sci. U.S.A. 109, 18613-18618. doi: 10.1073/pnas.12102 09109

Tsvetanova, N. G., and von Zastrow, M. (2014). Spatial encoding of cyclic AMP signaling specificity by GPCR endocytosis. Nat. Chem. Biol. 10, 1061-1065. doi: 10.1038/nchembio. 1665

Uhler, M. D., Chrivia, J. C., and McKnight, G. S. (1986). Evidence for a second isoform of the catalytic subunit of cAMP-dependent protein kinase. J. Biol. Chem. 261, 15360-15363.

Ukena, D., Shamim, M. T., Padgett, W., and Daly, J. W. (1986). Analogs of caffeine: antagonists with selectivity for A2 adenosine receptors. Life Sci. 39, 743-750. doi: 10.1016/0024-3205(86)90023-8

Van Bogaert, P. P., and Pittoors, F. (2003). Use-dependent blockade of cardiac pacemaker current (If) by cilobradine and zatebradine. Eur. J. Pharmacol. 478, 161-171. doi: 10.1016/j.ejphar.2003.08.083

Vandeput, F., Wolda, S. L., Krall, J., Hambleton, R., Uher, L., McCaw, K. N., et al. (2007). Cyclic nucleotide phosphodiesterase PDE1C1 in human cardiac myocytes. J. Biol. Chem. 282, 32749-32757. doi: 10.1074/jbc.M7031 73200

Vang, A. G., Ben-Sasson, S. Z., Dong, H., Kream, B., DeNinno, M. P., Claffey, M. M., et al. (2010). PDE8 regulates rapid Teff cell adhesion and proliferation independent of ICER. PLOS ONE 5:e12011. doi: 10.1371/journal.pone. 0012011

Van Wagoner, D. R., Pond, A. L., Lamorgese, M., Rossie, S. S., McCarthy, P. M., and Nerbonne, J. M. (1999). Atrial L-type Ca2+ currents and human atrial fibrillation. Circ. Res. 85, 428-436. doi: 10.1161/01.RES. 85.5.428

Vassilatis, D. K., Hohmann, J. G., Zeng, H., Li, F., Ranchalis, J. E., Mortrud, M. T., et al. (2003). The $\mathrm{G}$ protein-coupled receptor repertoires of human and mouse. Proc. Natl. Acad. Sci. U.S.A. 100, 4903-4908. doi: 10.1073/pnas.02303 74100

Wahl-Schott, C., Fenske, S., and Biel, M. (2014). HCN channels: new roles in sinoatrial node function. Curr. Opin. Pharmacol. 15, 83-90. doi: 10.1016/j.coph.2013.12.005

Weise, M., Vettel, C., Spiger, K., Gilsbach, R., Hein, L., Lorenz, K., et al. (2015). A systemic Pasteurella multocida toxin aggravates cardiac hypertrophy and fibrosis in mice. Cell. Microbiol. 17, 1320-1331. doi: 10.1111/cmi.12436

Williams, C. (2004). cAMP detection methods in HTS: selecting the best from the rest. Nat. Rev. Drug Discov. 3, 125-135. doi: 10.1038/nrd1306

Willoughby, D., and Cooper, D. M. (2007). Organization and Ca2+ regulation of adenylyl cyclases in cAMP microdomains. Physiol. Rev. 87, 965-1010. doi: 10.1152/physrev.00049.2006

Willoughby, D., and Cooper, D. M. (2008). Live-cell imaging of cAMP dynamics. Nat. Methods 5, 29-36. doi: 10.1038/nmeth1135

Wilson, M., Burt, A. R., Milligan, G., and Anderson, N. G. (1996). Wortmanninsensitive activation of p70s6k by endogenous and heterologously expressed Gi-coupled receptors. J. Biol. Chem. 271, 8537-8540. doi: 10.1074/jbc.271. 15.8537

Xiao, R. P. (2001). Beta-adrenergic signaling in the heart: dual coupling of the beta2-adrenergic receptor to $\mathrm{G}(\mathrm{s})$ and $\mathrm{G}(\mathrm{i})$ proteins. Sci. STKE 2001:re15. doi: 10.1126/stke.2001.104.re15

Xie, M., Rich, T. C., Scheitrum, C., Conti, M., and Richter, W. (2011). Inactivation of multidrug resistance proteins disrupts both cellular extrusion and intracellular degradation of cAMP. Mol. Pharmacol. 80, 281-293. doi: 10.1124/mol.111.071134

Yang, G., McIntyre, K. W., Townsend, R. M., Shen, H. H., Pitts, W. J., Dodd, J. H., et al. (2003). Phosphodiesterase 7A-deficient mice have functional T cells. J. Immunol. 171, 6414-6420. doi: 10.4049/jimmunol.171. 12.6414

Yong, Q. C., Pan, T. T., Hu, L. F., and Bian, J. S. (2008). Negative regulation of beta-adrenergic function by hydrogen sulphide in the rat hearts. J. Mol. Cell. Cardiol. 44, 701-710. doi: 10.1016/j.yjmcc.2008.01.007

Yu, J., Wolda, S. L., Frazier, A. L., Florio, V. A., Martins, T. J., Snyder, P. B., et al. (1997). Identification and characterisation of a human calmodulin-stimulated phosphodiesterase PDE1B1. Cell. Signal. 9, 519-529. doi: 10.1016/S08986568(97)00046-6

Zaccolo, M., De Giorgi, F., Cho, C. Y., Feng, L., Knapp, T., Negulescu, P. A., et al. (2000). A genetically encoded, fluorescent indicator for cyclic AMP in living cells. Nat. Cell Biol. 2, 25-29. doi: 10.1038/71345 
Zaccolo, M., and Movsesian, M. A. (2007). cAMP and cGMP signaling cross-talk: role of phosphodiesterases and implications for cardiac pathophysiology. Circ. Res. 100, 1569-1578. doi: 10.1161/CIRCRESAHA.106.144501

Zaccolo, M., and Pozzan, T. (2002). Discrete microdomains with high concentration of cAMP in stimulated rat neonatal cardiac myocytes. Science 295, 1711-1715. doi: 10.1126/science.1069982

Zhang, G., Liu, Y., Ruoho, A. E., and Hurley, J. H. (1997). Structure of the adenylyl cyclase catalytic core. Nature 386, 247-253. doi: 10.1038/386247a0

Zhang, R., Khoo, M. S., Wu, Y., Yang, Y., Grueter, C. E., Ni, G., et al. (2005). Calmodulin kinase II inhibition protects against structural heart disease. Nat. Med. 11, 409-417. doi: 10.1038/nm1215

Zhu, W. Z., Wang, S. Q., Chakir, K., Yang, D., Zhang, T., Brown, J. H., et al. (2003). Linkage of beta1-adrenergic stimulation to apoptotic heart cell death through protein kinase A-independent activation of $\mathrm{Ca} 2+/$ calmodulin kinase II. J. Clin. Invest. 111, 617-625. doi: 10.1172/JCI200316326

Conflict of Interest Statement: The authors declare that the research was conducted in the absence of any commercial or financial relationships that could be construed as a potential conflict of interest.

Copyright (c) 2015 Boularan and Gales. This is an open-access article distributed under the terms of the Creative Commons Attribution License (CC BY). The use, distribution or reproduction in other forums is permitted, provided the original author(s) or licensor are credited and that the original publication in this journal is cited, in accordance with accepted academic practice. No use, distribution or reproduction is permitted which does not comply with these terms. 